\title{
Flood basalts, continental breakup and the dispersal of Gondwana: evidence for periodic migration of upwelling mantle flows (plumes)
}

\author{
A. Segev \\ Geological Survey of Israel, 30 Malkhe Israel Street, Jerusalem 95501, Israel (Email: amit.segev@ mail.gsi.gov.il)
}

Received: 18 October 2000 - Revised: 27 December 2001 - Accepted: 4 March 2002

\begin{abstract}
The present study used igneous provinces, mainly continental flood volcanics or oceanic plateaus, at times associated with regional updoming, major rifting and continental breakup, together with its precisely dated magmatic events, as indications for paths of plume activity. First-generation plumes - such as the Permo-Carboniferous European-northwest African "EUNWA", and the Jurassic Karoo and Northwest Australia - and convergent environments (Variscan Orogen, the Pacific and the Tethyan subduction zones, respectively) seem to be genetically associated. This may indicate that mantle plumes tend to be initiated by long-lived downwelling lithospheric slabs causing instabilities at the lower mantle boundary layers.
\end{abstract}

First-generation plumes are larger (diameter ca. $3000 \mathrm{~km}$ ) than the late-generation plumes (ca. $2000 \mathrm{~km}$ ) and apparently have a radial dispersion of magmatism and rifting. These plumes ramified spatially and a second generation of plumes, commonly splitting to two offshoots, and even a third generation developed, acting in a similar temporal rhythm ( $\sim 60$ m.y. plume activity followed by $\sim 20$ m.y. of quiescence).

The Indian path consists of an exceptionally relatively short-lasting swarm of plumes: Rajmahal-Kerguelen ( $\sim 20$ m.y.), Madagascar ( 8 m.y.) and Deccan ( 7 m.y.), whose migration significantly changed course from the main trend. The recurrent consequential breakup and formation of spreading centers along this path is indicative of migration below the upper mantle circulation. This swarm of plumes may also point to a similar Lower mantle source that was influenced by a northeastward weak flow.

Although plume migration is suggested to have taken place in the lower mantle, the expansion of magmatism within igneous provinces is probably due to sub-lithospheric migration of the plume.

Key words. Gondwana; flood basalts; LIP; mantle plume; Variscan; Karoo; Paraná; Rajmahal; Deccan; Afar

\section{Introduction}

The causes of repeated supercontinent breakups following intraplate deformation and intensive magmatic outpouring are still a controversial issue (Bott, 1992; Storey, 1995; Sheth, 1999). Although some models suggest lithospheric extension and magmatism in response to subduction (Storey et al., 1992), plate tectonic reorganization (Anderson, 1994a, b), or convective partial melting (Mutter et al., 1988), the mantle plume model has gained widespread acceptance (White and McKenzie, 1989, 1995; Richards et al., 1989; Kent, 1994; Storey and Kyle, 1997; Tackley, 2000).

It is likely that large mantle plumes ascending from a thermal layer just above the core-mantle boundary $(\sim 2800 \mathrm{~km})$ are a result of lower mantle upwelling (Olson et al., 1990; Griffiths and Campbell, 1990). Griffiths and Campbell's (1990) model predicts that such plume heads attain a diameter of $800-1200 \mathrm{~km}$.

A common view of lower mantle upwelling is that it has the capacity to generate large quantities of basaltic magma (White and McKenzie, 1989; Campbell and Griffiths, 1990; Duncan and Richards, 1991; Schilling et al., 1992; Lanyon et al., 1993; Weaver et al., 1994; Coffin and Eldholm, 1994; Wilson and Guiraud, 1998) generally as continental flood volcanics (CFV) or flood basalts (FB), and oceanic plateaus. The overall area where extrusive and intrusive activity took place in relation to a mantle plume is termed an igneous province, and the relatively limited area where the igneous rocks have a plume signature is termed the plume province.

Since Morgan (1971), the role of lower mantle upwelling in continental breakup has been discussed by many investigators (e.g. Storey, 1995; Courtillot et al., 1999; Hawkesworth et al., 1999; Segev, 2000a). Segev (2000a) points out the evolutionary scenario in which parts of the oceanic basins developed after continental breakup resulting from plume activity. The penetration of such a plume head into the upper mantle is presumed to cause major stirring in the upper mantle convective cells (Griffiths and Campbell, 1990) and therefore causes antithetical circulation in the upper mantle. 
Subsequently, the adjustment of this contradictory convection will produce divergent environments in the upper mantle convection cells that lead to continental extension, heating the base of the lithosphere, regional domal uplift, rifting and breakup of the continental lithosphere, massive igneous activity (flood volcanics), spreading and drifting.

The disintegration of the Gondwana supercontinent since Early Mesozoic times has been generally connected to CFVs; and the state of preservation of most of its continental fragments is excellent. Therefore, they serve best for testing the relationships between mantle upwellings (plumes) and the above and nearby plate behavior by means of vertical movements, magmatism, breakup and drifting (geological evidence). The drifting, or plate tectonics, which is suggested to be the surface expression of "normal" or upper mantle convection (Olson et al., 1990) was reconstructed on the base of seafloor magnetic anomalies (geophysical evidence).

This work, which is an interpretation and synthesis of evidence from many detailed studies dealing with the MesozoicCenozoic igneous provinces and the fragmentation of Gondwana, attempts to understand the spatial and temporal relationships between these provinces. Such knowledge may shed light on the evolution of upwelling mantle flows and their role in continental breakup processes. The evidence applied is:

(a) the distribution of igneous provinces and their associated principal rifts, which subsequently developed to oceanic spreading centers;

(b) reliable radiometric ages of the beginning and termination of the magmatic events caused by mantle upwelling;

(c) paleogeographic reconstruction and the tectonic setting of the relevant lithospheric plates.

By adopting mantle upwelling concepts, also termed mantle diapirs, mantle plumes and also called here upwelling mantle flow, the present paper first describes the initial geodynamic setting and the first generation plume activity in central Pangaea. This is followed by a description of the closely associated igneous provinces that developed along the same trend or path. A similar methodology is used for southern Gondwana, where the description begin with the Karoo igneous province, and in eastern Gondwana, with the northwest Australia igneous province.

\section{Initial geodynamic setting and the first tectonomag- matic period in central Pangaea - the European-NW African province}

The Carboniferous Variscan (Hercynian) orogen resulted from the collision of Gondwana, several Gondwana-derived microplates, and Laurussia (e.g. Franke, 1989; Ziegler, 1989, 1990; Dallmeyer et al., 1995) during the final assembly stage of the Pangaea supercontinent (Fig. 1). The regional stress

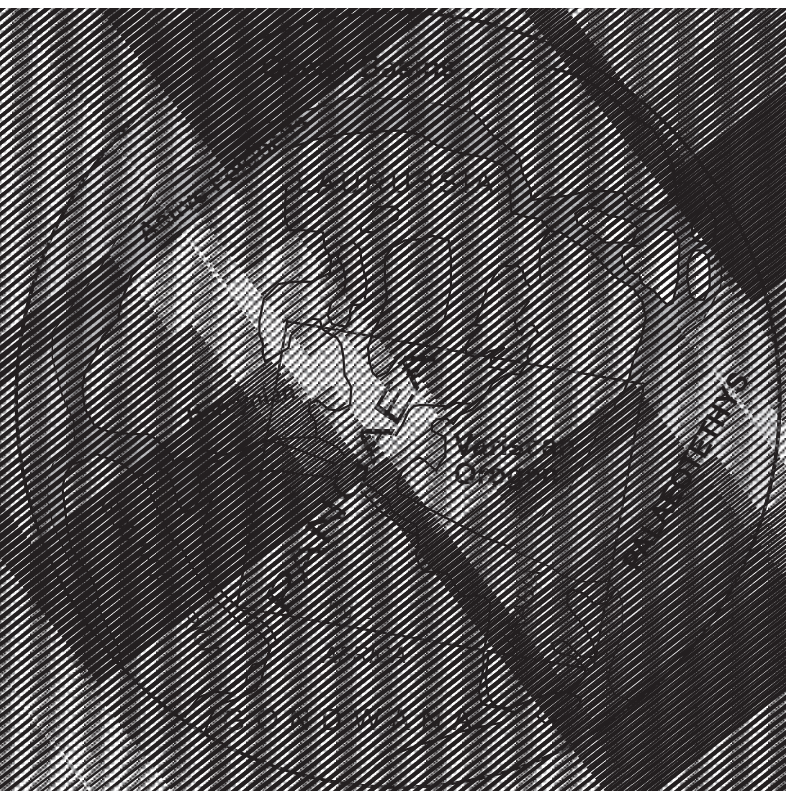

Fig. 1. Schematic reconstruction of the Permo-Carboniferous Pangaean supercontinent from Ziegler (1989). The frame marks the location of Fig. 2.

field reorganized from compression to post-convergent extension at about $305 \mathrm{Ma}$ (Ziegler, 1990; Burg et al., 1994), or even earlier at about $320 \mathrm{Ma}$ when the associated magmatism began (reviewed by Henk, 1999). It resulted primarily not from the gravitational forces inherited from the Variscan crustal thickening but from other tensile forces (Henk, 1999). Possible forces were:

(a) external (tectonic) - plate boundary forces (e.g. Dewey, 1988), far-field stresses related to a dextral translation of Gondwana relative to Laurussia (Ziegler, 1990, 1993); and

(b) internal (buoyancy) - mantle upwelling, active mantle plume.

The post-convergent extension is typified by crustal thinning, low viscosity of the lower crust, significant uplift, formation of numerous sedimentary basins (basin-and-range type, Lorenz and Nicholls, 1984; Ménard and Molnar, 1988) and widespread alkaline/subalkaline magmatism between $\sim 320$ and $240 \mathrm{Ma}$, which started in the Moldanubian Zone and spread outward toward the forelands. At the Oslo rift the magmatism lasted between 300 and $240 \mathrm{Ma}$ (Neumann et al., 1992). These magmas derived from partial melting of lower crustal rocks as well as mantle-derived melts (Lorenz and Nicholls, 1984).

Doblas et al. (1998) reviewed this igneous activity and enlarged its province toward northwest Africa (Europeannorthwest African province - EUNWA). By suggesting a super-plume activity in this province (Fig. 1), the latter authors followed the mantle uprising hypotheses of Lorenz and Nicholls (1976) and Ziegler (1990). During the same 


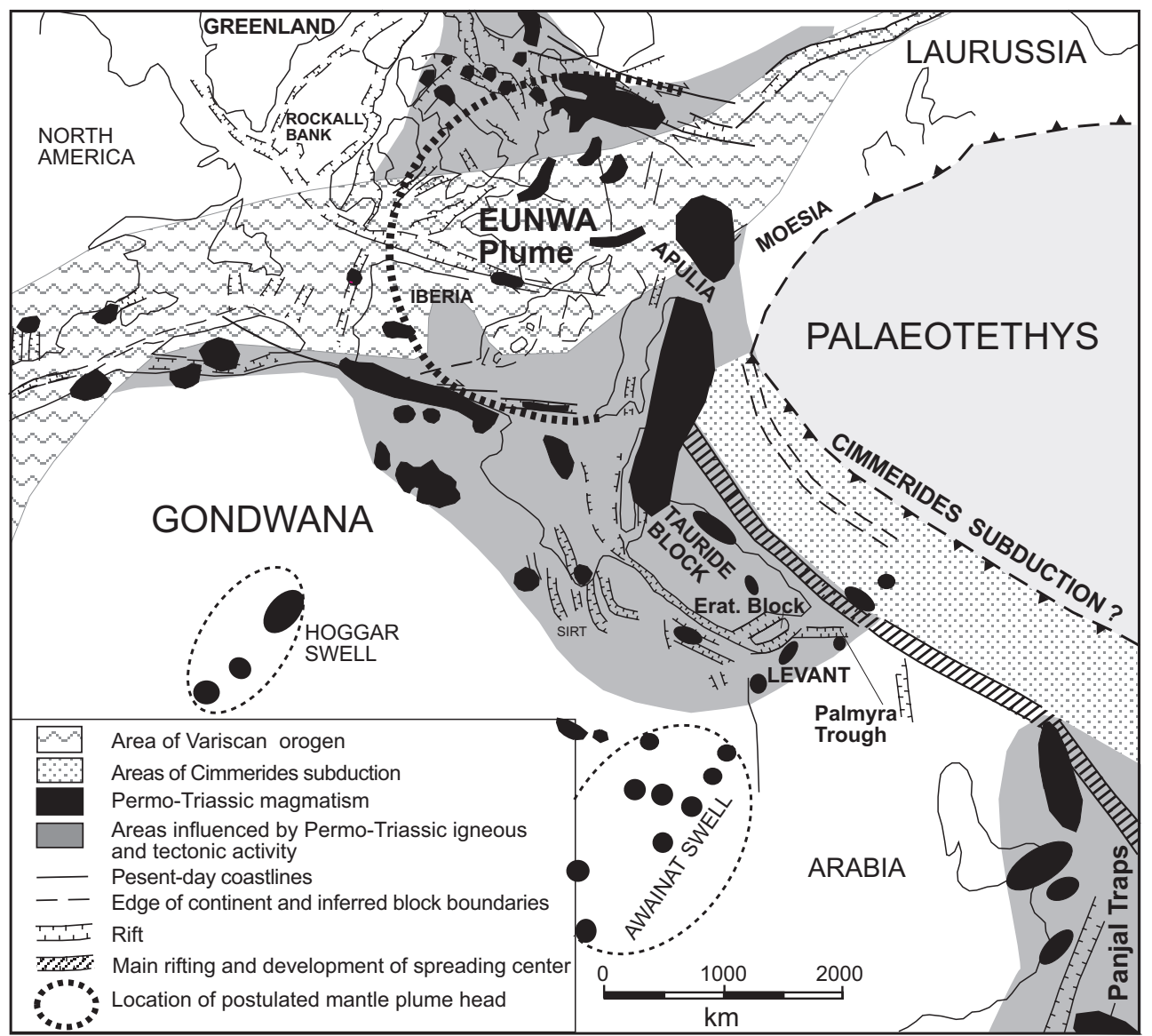

Fig. 2. Simplified tectonomagmatic setting in the Late Permo-Carboniferous times. Plate reconstruction mainly after Sengör et al. (1984), and the East Mediterranean after Garfunkel (1998). The magmatism is mainly according to Doblas et al. (1998) and Wilson and Guiraud (1998). The location of the postulated European northwest African (EUNWA) plume head is according to Doblas et al. (1998).

time, an extensive rift system developed in northern Europe (e.g. Oslo Rift, Skagerk Graben, and North German Basin) (Ziegler, 1990). Van Wees et al. (2000) interpreted the wrench faulting, uplifting, erosion, and intense magmatism in the North German Basin as due to localized divergent wrench-induced decompression melting of the asthenosphere and lithospheric boundary layer.

The Levant and NE Africa area, which was affected by major uplifting, rifting and magmatism, was situated at the SE edge of the EUNWA province. From the limited available geochronological evidence, we can presume magmatic events at ca. 275, 260 and $245 \mathrm{Ma}$ (Segev, 2000a, b; Segev and Eshet, in press, 2003).

The disintegration of the Hercynian orogen marked the beginning of the dispersal of the Pangaea supercontinent, and the main rift/drift southeastward from the EUNWA igneous province caused the northward drifting of the Cimmeride micro-continent (Sengör et al., 1984; Guiraud, 1998; Stampfli, 2000) by the opening of the Permo-Triassic Neotethys (Fig. 2).

\section{The southwestern (Central Atlantic) path}

\subsection{The Jurassic Central Atlantic province}

The large igneous province (ca. $5000 \mathrm{~km}$ length) in northwest Gondwana (after White and McKenzie, 1989; Hill, 1991; McHone, 1996; Wilson, 1997; Wilson and Guiraud, 1998) represents the extension, breakup and the formation of the Central Atlantic Ocean (Fig. 3). The eastern part of this province extends from Iberia (Europe) in the north (Sebai et al., 1991, Deckart et al., 1997) through West Africa (Morocco, western Algeria, Mauritania, Mali, Guinea, Liberia) to northern South America (Guyana, Surinam, French Guyana, and northern Brazil - Maranhão, Roraima, Anari and Tapirapuã) (Deckart et al., 1997; Baksi and Archibald, 1997; Marzoli et al., 1999). The western part extends over North America's eastern margins, from Nova Scotia, Canada, in the north down to South Carolina, U.S. (e.g. Sutter, 1985; Dunning and Hodych, 1990; Hodych and Dunning, 1992).

Many ${ }^{40} \mathrm{Ar} /{ }^{39} \mathrm{Ar}$ ages as well as $\mathrm{U} / \mathrm{Pb}$ zircon ages (see above-mentioned references; reviewed in detail by Segev, 2000a) point to a relatively long initial magmatic event between 202 and $189 \mathrm{Ma}$. Several analyses indicate a magmatic phase at ca. $171 \mathrm{Ma}$ (reviewed by Cahen et al., 1984). 


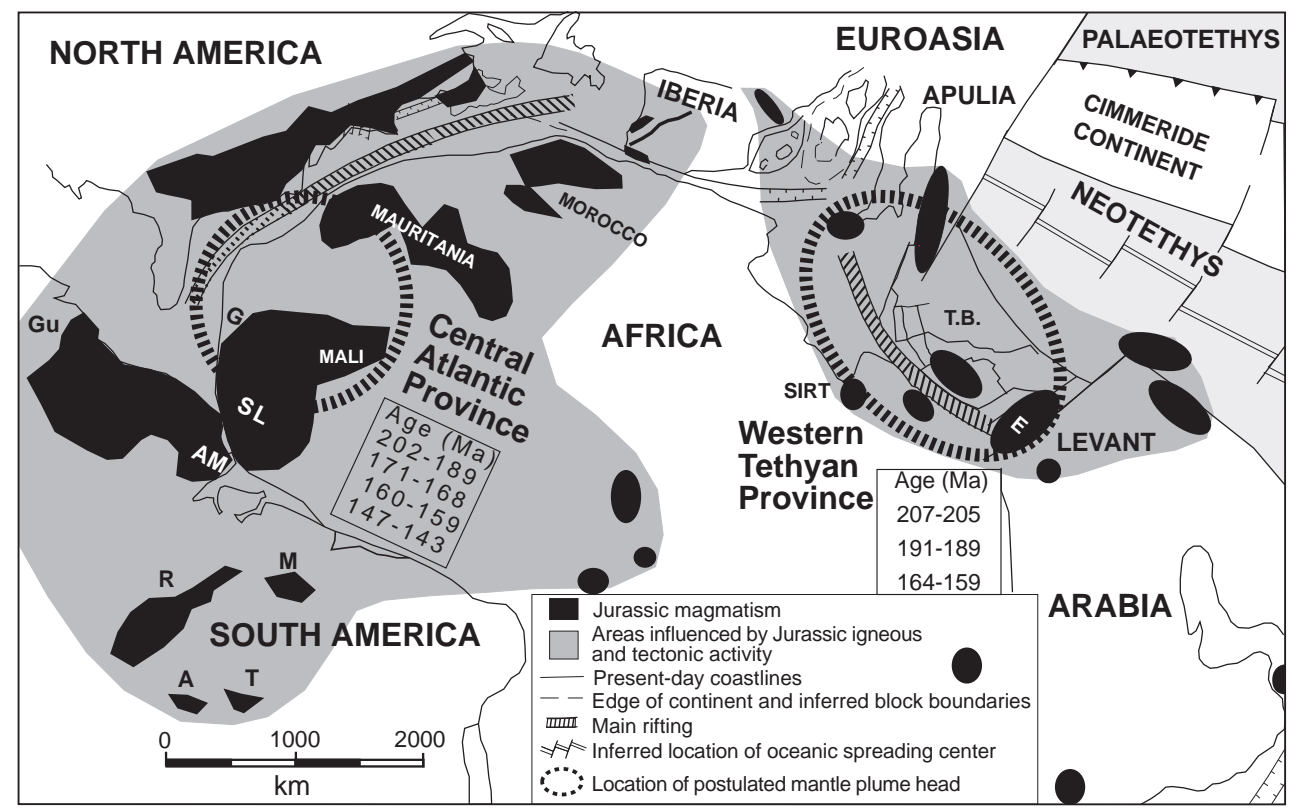

Fig. 3. Simplified tectonic setting of the northern Gondwana region in the Jurassic times after Sengör (1979) and Guiraud (1998). Distribution of magmatism is according to Hill (1991), Deckart et al., (1997), Wilson (1997), Wilson and Guiraud (1998), Segev (2000b) and Marzoli et al. (1999). The location of the Central Atlantic plume head is according to White and McKenzie (1989), McHone (1996) and Wilson (1997), whereas the postulated Western Tethyan plume head is according to Segev (2000a). For geochronological data see text. Abbreviations.: E Eratosthenes; T. B. - Tauride Block; G - Guinea; SL - Sierra Leone; AM - Amapá; Gu - Guyana; R - Roraima; M - Maranhão; A - Anari; and $\mathrm{T}$ - Tapirapuã.

The young magmatic phases are 159-160 m.y. in northern Brazil (Baksi and Archibald, 1997), and bimodal alkaline transitional basalts and peralkaline rhyolites of $146.7 \pm 1.6-$ $143.1 \pm 1.5$ m.y. from the northern Benue Trough (Maluski et al., 1995), and along the Liberian margin (Martin, 1982), Equatorial Atlantic.

Oliveira et al. (1990), Hill (1991), McHone (1996), Wilson (1997) and Wilson and Guiraud (1998) connect this igneous province to a plume.

\subsection{The Cretaceous West Africa-Equatorial Atlantic province}

After a very short quiescence, the next magmatic events in the northern Benue Trough (Fig. 4), were between $138.8 \pm 1.8$ and $130.7 \pm 2.7 \mathrm{Ma}$, ca. $123.1 \pm 1.6 \mathrm{Ma}$ and ca. $106 \mathrm{Ma}$ (Maluski et al., 1995). Volcanoclastic deposits along the Ghanean margin, West Africa, yielded 120-125 Ma (Reyre, 1984). Alkali rhyolitic dikes and phonolites from the southern Benue Trough yielded ages between 97.1 \pm 1.2 and $92.3 \pm 1.1 \mathrm{Ma}, 87.7 \pm 1$ and $81.1 \pm 1.1 \mathrm{Ma}$, whereas the episode at $75-70 \mathrm{Ma}$ is not considered as volcanic age emplacement, and the last volcanic event was between 68 and $49 \mathrm{Ma}$.

The magmatism in the Benue Trough is partly contemporaneous with that of NE Brazil along the Potiguar rift and in the Maranhão basin ( 129-124 Ma; Baksi and Archibald, 1997). They both were associated with the opening of the Equatorial Atlantic and related by Wilson and Guiraud $(1992,1998)$ to the St. Helena mantle plume.

\section{The southeastern (Tethyan) path}

\subsection{The Jurassic western Tethyan province}

Deep erosion of upper Triassic units and the absence of Early Jurassic rocks in the Levant and NE Africa (Conway, 1990; Keeley and Massoud, 1998) indicate major uplift and denudation of the Arabian-Nubian area (Fig. 3). Similar evidence was also reported from the Tauride block (e.g. Monod and Akay, 1984). Furthermore, Lower Jurassic faulting (Garfunkel and Derin, 1984) accompanied by alkaline magmatism (Kohn et al., 1993) is known mainly from northern Israel drillholes, but also from the Negev (Baer et al., 1995; Segev et al., 1996). Segev (2000a) reinterpreted ${ }^{40} \mathrm{Ar} /{ }^{39} \mathrm{Ar}$ data and differentiated two magmatic events, namely ca. 207-205 and 191-189 Ma in the Early Jurassic, and added an inferred volcanic event (based on an estimated ${ }^{40} \mathrm{Ar} /{ }^{39} \mathrm{Ar}$ age) at ca. $160 \mathrm{Ma}$, coeval with a large Callovian hiatus and volcanism in Lebanon.

In northern Libya, granodiorites of ca. $207 \mathrm{Ma}$ are known from the Uaddan and Amal horsts, having later stage basalt (164 Ma), rhyolite (161 Ma) and microsyenite (159 Ma) magmatism, coeval with rhyolite ( $160 \mathrm{Ma})$ from the Zelten horst (Cahen et al., 1984; Massa and Delort, 1984). Correlative 
magmatic rocks have also been found in oil wells in the northern Western Desert of Egypt (Keeley and Wallis, 1991).

The widespread early Jurassic tholeiitic and alkaline magmatism in the eastern Mediterranean and NE African areas suggest that the main rift/drift event occurred during the Jurassic tectono-magmatic period. During this period the Mesotethys, or the present eastern Mediterranean area, began to open.

\subsection{The Cretaceous Levant-Nubia province}

After a quiescence of ca. 22 m.y. following the final magmatic activity in the Western Tethys province, a regional uplift and extensive denudation in the Levant area is well documented (Fig. 4). At the beginning of the Cretaceous, a swell, several hundred kilometers wide, formed from Lebanon and Syria to Sinai (Garfunkel, 1989, 1998), and a similar feature is documented in northern Egypt, Libya, and Sudan (Reynolds et al., 1997). Five cycles of magmatic events and quiescent intervals in Israel have been interpreted based on ${ }^{40} \mathrm{Ar} /{ }^{39} \mathrm{Ar}$ ages (Segev, 1998, 2000a; Segev and Lang, 2001), namely: 138-132, 125-123, 116.5-107, 98.5-94 m.y. and $82 \mathrm{Ma}$. The extrusive (prominently in northern Israel) and intrusive rocks, some of them exposed, are mainly subalkaline to alkaline basalts together with nephelinites, basanites, micro-gabbros, quartz-syenites and trachytes (Stein and Hofmann, 1992). All these rocks are enriched in incompatible elements (e.g. LREE) and related to mantle plume (Stein and Hofmann, 1992, 1994). Some of the magmatic events marked local uplifts and erosion (Fig. 4). Early Cretaceous basalt flows also cover wide regions in the Mardin Plateau and Palmyrides of Syria, and within the margins of the Euphrates graben in Iraq (Wilson and Guiraud, 1998). Poorly age-constrained basalts are known from the Gulf of Suez (115-125 m.y.; Meneisy, 1990) and the Southeastern Desert of Egypt (ca. 141 and $90 \mathrm{Ma}$, Serencsits et al., 1981).

Although the timings of the Cretaceous magmatic cycles in the Levant are well constrained, the geodynamic processes are less well-known. According to the plume evolution scenario, we would expect to find evidence for a rift/drift zone that might have been opened during this period. Such evidence has not yet been found and we can speculate that the explanations for the geodynamic processes in the Levant during mid-Cretaceous times may come from the major change of the plate tectonic regime when Africa and Euroasia began to converge. Though initiation of subduction in the Mesotethys is constrained by the 90-92 Ma age of the Troodos complex (Garfunkel, 1998), the decay of the lithospheric stretching probably started in Early Cretaceous times. Therefore, the coexisting thermal plume caused thinning of the lithosphere, regional uplift, melting within the crust and the rise of magmas to the surface, without successful rifting. The decay of the Cretaceous plume in northern Gondwana marks the end of the lower mantle upwelling along the Tethyan super-province (Segev, 2000a).

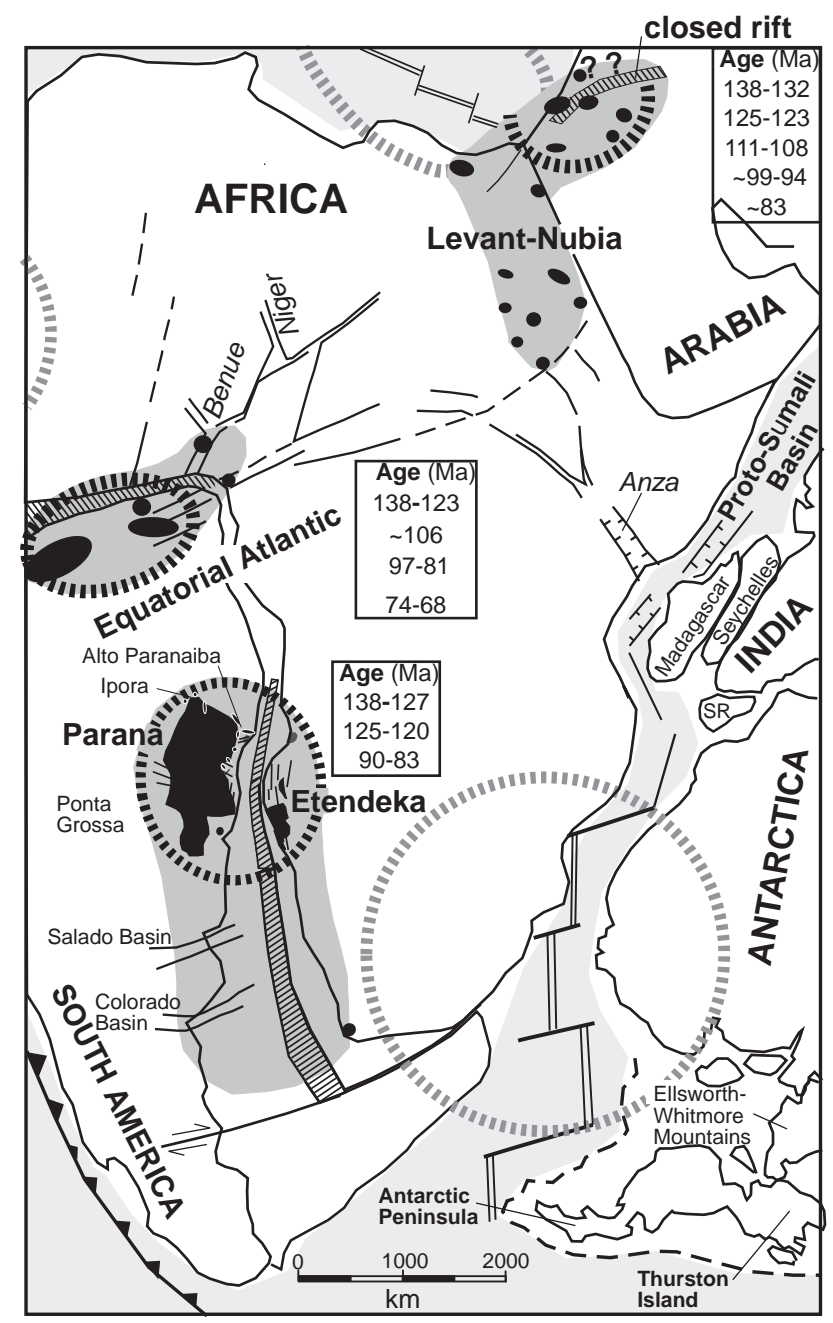

Fig. 4. Tectonic setting of western Gondwana region in the Cretaceous times (after Asmus and Baisch, 1983; Reynolds et al., 1997) showing three contemporaneous igneous and plume provinces: Equatorial Atlantic, Paraná-Etendeka and Levant-Nubia, and their consequent breakups. The gray dashed lines mark the postulated location of the previous Jurassic plumes. For sources of magmatic distribution, location of plume head and geochronology, see text.

\section{The first tectonomagmatic period in southern Gond- wana - the Karoo province}

Before Early Jurassic times, the Gondwana supercontinent was bound on its southern (Proto-Pacific) side (Fig. 5) by an active subduction zone that formed the fold belts of South Africa, South America and southwest Antarctica (Ellsworth and Pensacola mountains) (e.g. Storey et al., 1992; Storey, 1995).

The initial Jurassic igneous activity in South Africa probably started ca. $204 \pm 5 \mathrm{Ma}\left({ }^{40} \mathrm{Ar} /{ }^{39} \mathrm{Ar}\right.$ and $\mathrm{Rb} / \mathrm{Sr}$, Allsop and Roddick, 1984; Kent et al., 1992) at the northern margins of the Karoo province. It began with minor nephelinitecarbonatite-ijolite sills in eastern Zimbabwe and Kruger Park, kimberlite pipes in northeast Swaziland, and alkali 


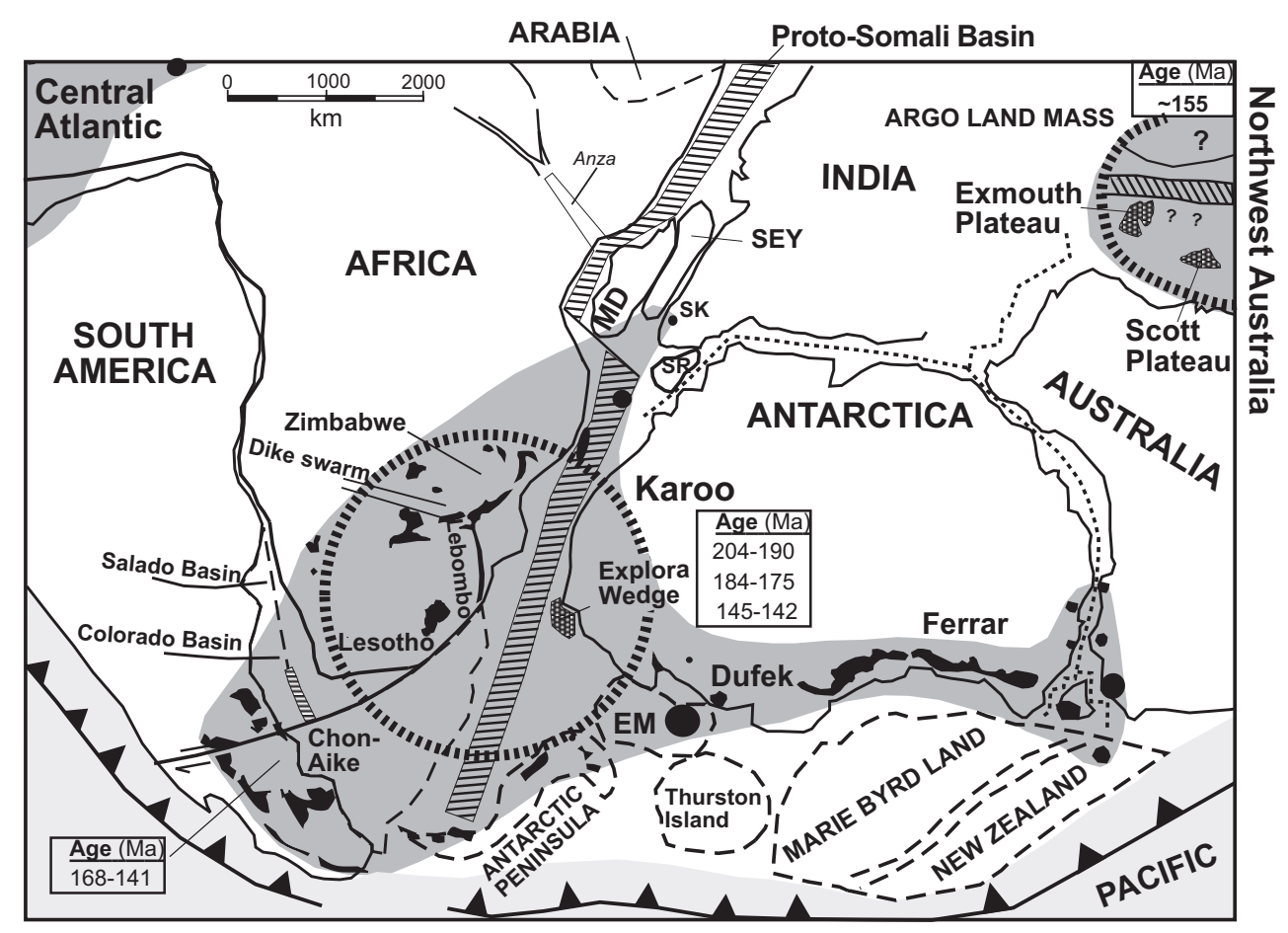

Fig. 5. Tectonic setting of southern Gondwana in the Jurassic times (mainly after Storey et al., 1992, and Lawver et al., 1992) showing the Karoo igneous and plume province, and the breakup between east and west Gondwana, as well as the less known Northwest Australia province. For sources of magmatism distribution, location of plume head and geochronology, see text.

basalts and basanites at northern Lebombo and western Zambia (Fig. 2; Eales et al., 1984). The age of the major tholeiite outpouring in Namibia, Lesotho, southern Lebombo and the Antarctic Ferrar province was between 184 and $175 \mathrm{Ma}$ (Minor and Mukasa, 1995; Brewer et al., 1996; Encarnación et al., 1996; Duncan et al., 1997; Elliot et al., 1999). In the Chon-Aike province at Patagonia, South America, Antarctic Peninsula and Ellsworth Land, the magmatism started ca. $190 \mathrm{Ma}$ (Millar and Pankhurst, 1987; Fanning and Laudon, 1997) and the main activity was also dated between 183 and $173 \mathrm{Ma}$ (Millar and Pankhurst, 1987; Pankhurst et al., 1998), with additional magmatism occurring between 168 and $141 \mathrm{Ma}$ (Millar et al., 1990; Alric et al., 1996; Féraud et al., 1999). This exceptionally long duration of the last magmatic event is probably due to the mixed environments continental extension and subduction (Féraud et al., 1999).

The last magmatic event (ca. $145 \mathrm{Ma}$ ) occurred at the tips of the Karoo igneous province, in Patagonia (Féraud et al., 1999), in the Antarctic Peninsula (Vaughan and Millar, 1995; Vaughan et al., 1998; Vaughan et al., 1998), in northern South Africa at the Bumbeni and Kuleni complexes (Hargraves et al., 1997; Allsopp et al., 1984), and up to south Kerala, southern India (Radhakrishna et al., 1999), and southeast Australia (Allen et al., 1997, 1998).

During the Jurassic period, the Karoo area was uplifted about $1.5 \mathrm{~km}$ (Cox, 1989), and the breakup of East Gondwana (India, Antarctica and Australia) from West Gondwana (Africa and South America) (Fig. 5) took place along a proto- oceanic rift - the Weddel Sea-Somali basin. This process was a result of the Karoo plume activity (Morgan, 1981; Cox, 1988; Duncan and Richards, 1991; Duncan et al., 1997).

\section{The eastern (Pacific) path}

6.1 The Cretaceous Marie Byrd Land - Eastern Australia province

Following a quiescence of $\sim 15$ m.y. after the final magmatic activity of the Karoo province (145-141 Ma), the initiation of magmatism in the Cretaceous was centered between Antarctica (Marie Byrd Land) and New Zealand (Weaver et al., 1994; Storey et al., 1999; Fig. 6). It comprised intensive activity along the eastern margin of Australia (Bryan et al., 1997), and some activity along the margins of the Antarctic Peninsula (Weaver et al., 1994; Vaughan et al., 1998). According to Bryan et al. (1997), this magmatism extended over $1500 \mathrm{~km}$, from the Whitesunday Volcanic Province and the Great Artesian Basin of northeast Australia, and the OtwayGippsland Basin of southeast Australia (Victoria and Tasmania). The continuation of this igneous province extended for more than $2000 \mathrm{~km}$ from Tasmania to the Antarctic Peninsula.

Intensive, probably Cretaceous, OIB-MORB-like tholeiitic basalt outpouring of the oceanic Hikurangi Plateau (Mortimer and Parkinson, 1996) is interpreted as having been closed to the Marie Byrd Land margin (Storey et al., 1999; 


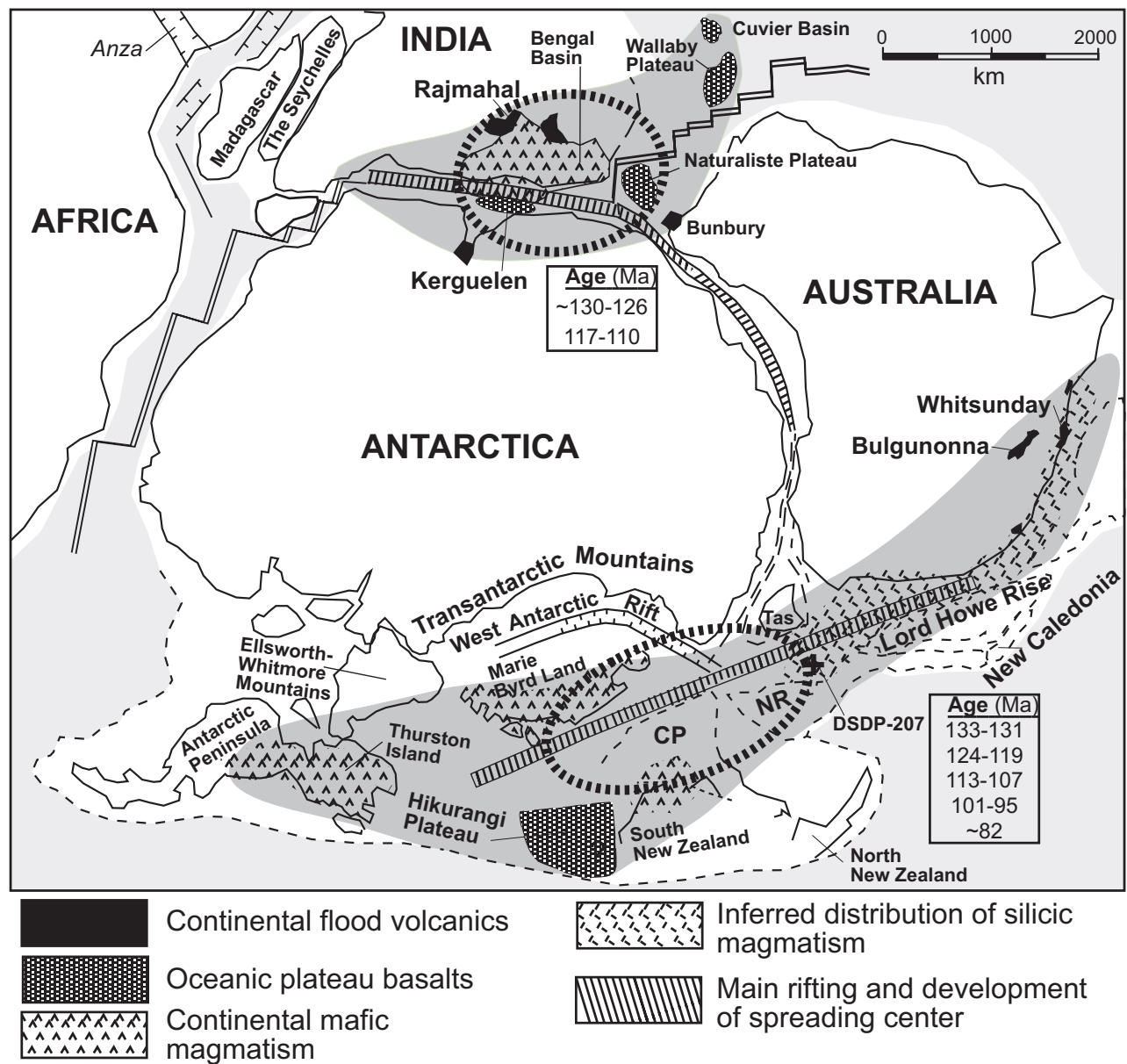

Fig. 6. Generalized reconstruction of Early Cretaceous eastern Gondwana (mainly after Veevers et al., 1991; Weaver et al., 1994, and Storey et al., 1999) showing: (1) the Rajmahal-Kerguelen igneous and plume province, and the breakup between India and Antarctica; (2) the passive rifting between Australia and Antarctica; and (3) the Marie Byrd Land-East Australia igneous and plume province, as well as its consequent breakups. For sources of distribution of magmatism, location of plume head and geochronology, see text.

Fig. 6). It is situated at present to the north of the Chatham Rise, covering some $350000 \mathrm{~km}^{2}$, and is interpreted as a region of thickened oceanic crust $(10-15 \mathrm{~km})$ related to a mantle plume (Davey and Wood, 1994; Mortimer and Parkinson, 1996). Storey et al. (1999; Fig. 6) related this plume-derived excess melt production to the Marie Byrd Land plume, which was also responsible for the Marie Byrd Land mafic dike complexes.

Reliable SHRIMP U/Pb ages from NE Australia (Allen et al., 1998), $\mathrm{Rb} / \mathrm{Sr}$ ages (listed in Bryan et al., 1997) and $\mathrm{K} / \mathrm{Ar}$ mineral ages from northeast Australia, define an igneous event between 133 and $131 \mathrm{Ma}$. The major volcanism recorded between 124 and $107 \mathrm{Ma}$ was probably divided into two magmatic events: $124-119$ m.y. and $\sim 113-107$ m.y. A younger magmatic event is recorded at about $95 \mathrm{Ma}$.

Syn-extensional granite from Marie Byrd Land yielded a $\mathrm{U} / \mathrm{Pb}$ zircon age of $110 \pm 1 \mathrm{Ma}$ (Mukasa et al., 1994), and the mafic dikes there average $107 \mathrm{Ma}(\mathrm{Ar} / \mathrm{Ar}$ laser step heating; Storey et al., 1999). Some of the dikes are younger and yielded a $\mathrm{U} / \mathrm{Pb}$ zircon age of $100.6 \pm 0.7 \mathrm{Ma}$ (Mukasa et al., 1994) and an Ar/Ar age of 99.9 Ma (Palais et al., 1993;
Mukasa et al., 1994).

Felsic rocks of extensional alkaline magmatism in the western province of New Zealand yielded SHRIMP U/Pb ages between 114 and $109 \mathrm{Ma}$ and at $82 \mathrm{Ma}$ (Waight et al., 1998). In the Antarctic Peninsula, the syn-extensional magmatism is dated between 141 (belonging to the Karoo province) and $127 \mathrm{Ma}$ (reviewed by Vaughan et al., 1998).

These igneous events fit well with the starting ages of continental extension phases between Australia and Antarctica (Veevers et al., 1990; Willcox and Stagg, 1990).

Sea-floor ages between SE Australia and the Lord Howe Rise, related to the opening of the Tasman Sea, range from about 85 to $55 \mathrm{Ma}$ (Veevers et al., 1991), when the spreading ceased.

Uplifting and rifting between Marie Byrd Land and New Zealand (Weaver et al., 1994; Storey et al., 1999) as well as in the West Antarctic rift system is probably episodic and started at $110 \mathrm{Ma}$ (according to fission-track age profiles, Stump and Fitzgerald, 1992). The mid-Cretaceous reconstruction (Sutherland, 1999) of the consequential spreading ridge is depicted in Fig. 7. 

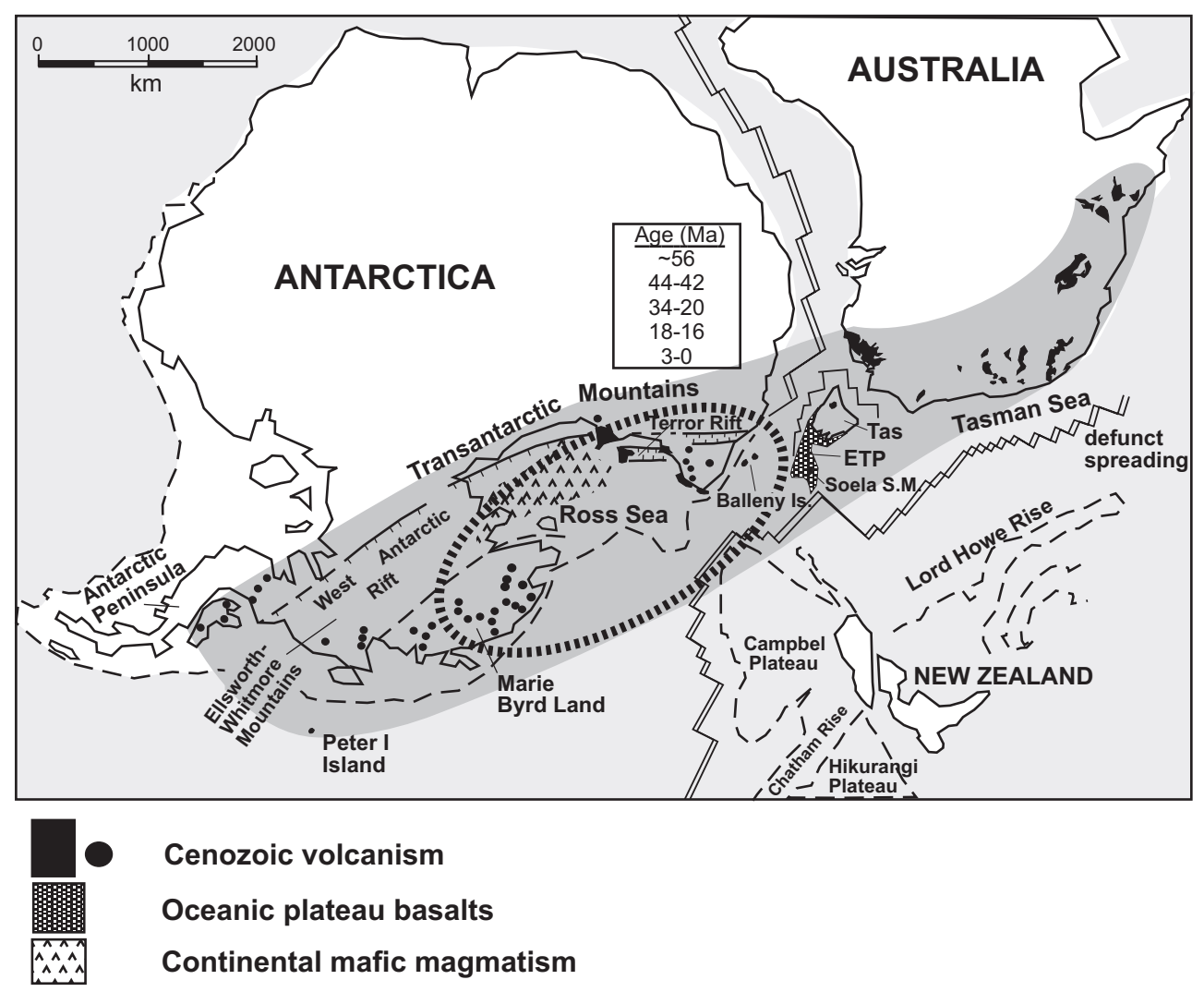

Fig. 7. Generalized reconstruction of Early Tertiary southeastern fragments of Gondwana showing the Cretaceous Tasman Sea spreading ridge, between 85-55 Ma (after Veevers et al., 1991; Sutherland, 1999), and the SE Indian spreading ridge (Veevers et al., 1990; Sutherland, 1999). Note the close relationships between the Tertiary-Recent Balleny and the Cretaceous Marie Byrd Land-East Australia igneous and plume provinces. Tas - Tasmania; ETP - east Tasmania plateau. For sources of distribution of magmatism, location of plume head and geochronology, see text.

The transition from Jurassic arc-magmatism to extensional magmatism along the Pacific margin of Gondwana, from the Antarctic Peninsula (Vaughan et al., 1998), through New Zealand (Waight et al., 1998) to NE Australia (Bryan et al., 1997), makes it difficult to identify the exact initiation of the Cretaceous plume head. Storey et al. (1999) (based on hot spot reconstruction) suggested that the plume head was located between Marie Byrd Land and New Zealand, but the earlier initiation of igneous activity in Eastern Australia and the location of the main rifts may position the plume head in the Tasman Sea. Therefore the latter sea opened over the Cretaceous plume and not over the Cenozoic Balleny plume.

\subsection{The Tertiary-Recent Ross Sea-Tasmania province (Bal- leny plume)}

Because the Ross Sea-Tasman igneous province extended (along ca. $4400 \mathrm{~km}$ ) over the same exposed areas as the previous Cretaceous Marie Byrd Land - Eastern Australia province, it is difficult to distinguish between their ending and beginning (Fig. 7).

The evidence that the Tasman Sea ridge ceased spreading at about $55 \mathrm{Ma}$ (Veevers et al., 1991) indicates some major changes in upper mantle circulation at this time. Although weak, Cenozoic igneous activities are reported from eastern Australia at ca. 56 and 44-42 Ma, the main basaltic outpouring took place between 34 and $20 \mathrm{Ma}$ (K/Ar dates; reviewed by Griffin et al., 1987). Basalts from the Soela Seamount on the East Tasman Plateau (ETP) yield an Ar/Ar age of 36 Ma (R.A. Duncan, in Lanyon et al., 1993), and the bend located at Soela is inferred to be $\sim 43 \mathrm{Ma}$. The tholeiitic to alkalic basalts of Tasmania yield ages between $\sim 59$ and $8 \mathrm{Ma}$ (Sutherland, 1989). Veevers et al. (1991) suggested that the ETP is a thick accumulation of basalt related to the Balleny plume activity.

Most of the quoted radiometric ages of this igneous province, which is still active at present, are K/Ar dates and therefore, the timing of the various magmatic events are not yet precisely established. The younger magmatic events in Eastern Australia occurred at 18-16 Ma and 3-0 Ma (listed by Griffin et al., 1987).

The Marie Byrd Land Cenozoic alkaline basaltic activity (reviewed by Storey et al., 1999) started at $\sim 30 \mathrm{Ma}$ and was associated with a positive geoide anomaly of $5-7 \mathrm{~m}$ with a diameter of $\sim 800 \mathrm{~km}$. It is differentially uplifted by 600 $2700 \mathrm{~m}$ over an area some $1000 \mathrm{~km}$ across, and with high heat flow. This, togeher with alkaline basalt volcanism as- 
sociated with the West Antarctic rift system (Kyle, 1990; Behrendt et al., 1994; Rocholl et al., 1995) at 30 Ma to Recent, is related to a mantle plume beneath Marie Byrd Land with a diameter of $\sim 600 \mathrm{~km}$ according to LeMasurier and Rex (1991) and $3500 \times 2000 \mathrm{~km}$ according to Behrendt et al. (1992). Lanyon et al. (1993), following Vogt and Johnson (1973), suggested a mantle plume beneath the Balleny Island chain. Contemporaneous alkaline volcanism is recorded along the Antarctic Peninsula (Hole and LeMasurier, 1994).

The Ross Sea-Tasmania province probably belongs to a large elongated mantle current centered somewhere beneath the Ross Sea and resulted in the cessation of the Tasman spreading ridge and the onset of the Southeast Indian Ridge between southern Australia and Antarctica.

\section{The northwestern (South Atlantic) path}

\subsection{The Cretaceous Paraná-Etendeka province}

The Paraná Paleozoic sedimentary basin has a present-day exposure of some $1.2 \times 10^{6} \mathrm{~km}^{2}$ where $\sim 75 \%$ of it is covered by Cretaceous magmatism (Piccirillo, et al., 1988) (Fig. 4). The flood volcanism in the Paraná and the equivalent Etendeka magmatism in Namibia produced $\sim 1.5 \times 10^{6} \mathrm{~km}^{3}$ of alkali volcanic rocks (Renne et al., 1992), ranging from basalts to rhyolites. The Paraná basin was subjected to extension in Jurassic-Early Cretaceous time (Asmus and Baisch, 1983) and the volcanism, which started at ca. $138 \mathrm{Ma}$ with a slow eruption rate, reached its maximum between 133 and $131 \mathrm{Ma}$ and ended at ca. $127 \mathrm{Ma}$ (Turner et al., 1994; Stewart et al., 1996). The voluminous phase of tholeiitic volcanism was at 133-129 Ma (Renne et al., 1992, 1996; Stewart et al., 1996; Deckart et al., 1998).

In northwestern Namibia, the most intense igneous activity took place between 134 and $130 \mathrm{Ma}$ (Milner et al., 1993). Some measurements of the Ponta Grossa dike swarm indicate minor magmatic events between 125 and $120 \mathrm{Ma}$, interpreted as reflecting the initiation of full drift in the adjacent South Atlantic opening (Renne et al., 1996). The Alto Paranaiba $\left(>15000 \mathrm{~km}^{3}\right)$ volcanic field, Ipora as well as hypabyssal intrusions, kimberlites, dikes and other mafic potassic bodies surrounding the Paraná basin, yielded ages mainly between 85 and $80 \mathrm{Ma}$ (Gibson et al., 1995, Deckart et al., 1998), and in western South Africa between 90 and $83 \mathrm{Ma}$ (Allsop and Barrett, 1975). Dikes near the coast yielded even younger ages ca. $70 \mathrm{Ma}$ (Deckart et al., 1998). These late magmatic events were interpreted by Gibson et al. (1995) as due to plume activity (Trindad plume), and they connect it to the Tertiary Trindad-Vitoria oceanic islands chain. VanDecar et al. (1995) found that a fossil plume still exists beneath South America even at the present day.

The Paraná-Etendeka igneous province is widely presumed to be related to the Tristan de Cunha plume (White and McKenzie, 1989; Turner et al., 1994) and the younger magmatic event ( $\sim 85 \mathrm{Ma})$, to the Trindad plume (Gibson et al., 1995).

\section{The initial tectonomagmatic period in northeastern Gondwana - the northwest Australia province}

An active subduction in NE Gondwana, at the Paleotethys side, was bound by the Cimmerian continental fragments (e.g. Lawver et al., 1992) before the Early Jurassic. Less information on the Jurassic igneous province has been reported from the northeastern edge of Gondwana (Fig. 5) from northwest Australia (Mutter et al., 1988, 1989; Hopper et al., 1992; Crawford and von Rad, 1994). Magmatic activity along this margin (Scott and Exmouth plateaus) is known from evolved trachytic to rhyolitic lavas of mainly Early Jurassic age (von Rad et al., 1992), which accompanied intensive intracratonic rifting. The magmatic activity near the Rowley Terrace-Scott plateau and the Exmouth plateau ended at $\sim 155 \mathrm{Ma}$ (K-Ar date, Ludden, 1992) after a period of extension, rifting and breakup (Powell et al., 1988; Mutter et al., 1989, Veevers et al., 1991). White and McKenze (1989) related the west Australian plateau basalts to "a broad thermal anomaly generated by a mantle plume", whereas Crawford and von Rad (1994) attributed the Rowley Terrace-Scott plateau and Exmouth plateau to the Jurassic magmatism that jumped southward to the Wallaby and Naturaliste plateaus some 20-25 m.y. later (Valanginian) as part of the Kerguelen-Rajmahal plume.

\section{The western (Indian) path}

\subsection{The Early Cretaceous Rajmahal - Kerguelen province}

Extensional movements in "Greater India", East Antarctica and the western Australian margin (Kent, 1991) resumed during the Early Cretaceous after a long period of extension, rifting, breakup and drifting between northwest Australia-India and the Argo Land Mass (Powell et al., 1988) (Figs. 5, 6).

According to Crawford and von Rad (1994) the breakup between India and Western Australia along the Cuvier and Gascoyne Abyssal Plains began around M11-M10 (132$130 \mathrm{Ma})$. The plateau basalts in this region that constitute the Wallaby and the Naturaliste plateaus are related to the Kerguelen-Rajmahal plume (Kent, 1991; Crawford and von $\mathrm{Rad}, 1994)$. The ${ }^{40} \mathrm{Ar} /{ }^{39} \mathrm{Ar}$ ages of the Bunbury basalts in southwest Australia, which are part of the volcanism in the Naturaliste and the Wallaby plateaus, is $130 \pm 0.5 \mathrm{Ma}$ (Pringle et al., 1994) and $115 \pm 2 \mathrm{Ma}$ (Colvell et al., 1994).

The uplift at the India-Antarctica boundary reached a maximum in the Early Cretaceous, when a variety of igneous rocks were emplaced into the East Antarctic and northeast Indian graben. On the northeastern Indian continent, the Rajmahal (exposed), Bengal (covered by the Gangetic alluvium) and Sylhet (exposed $\sim 400 \mathrm{~km}$ east of Rajmahal) traps initially covered $\sim 2 \times 10^{5} \mathrm{~km}^{2}$, and form a single flood basalt province (Baksi, 1995). It consists of quartz tholeiites, alkali basalts and andesites with a total thickness of up to $600 \mathrm{~m}$, which probably are linked to a variety of alkali igneous rocks (lamproites, lamprophyrs, pyroxenites, carbonatites and ijo- 


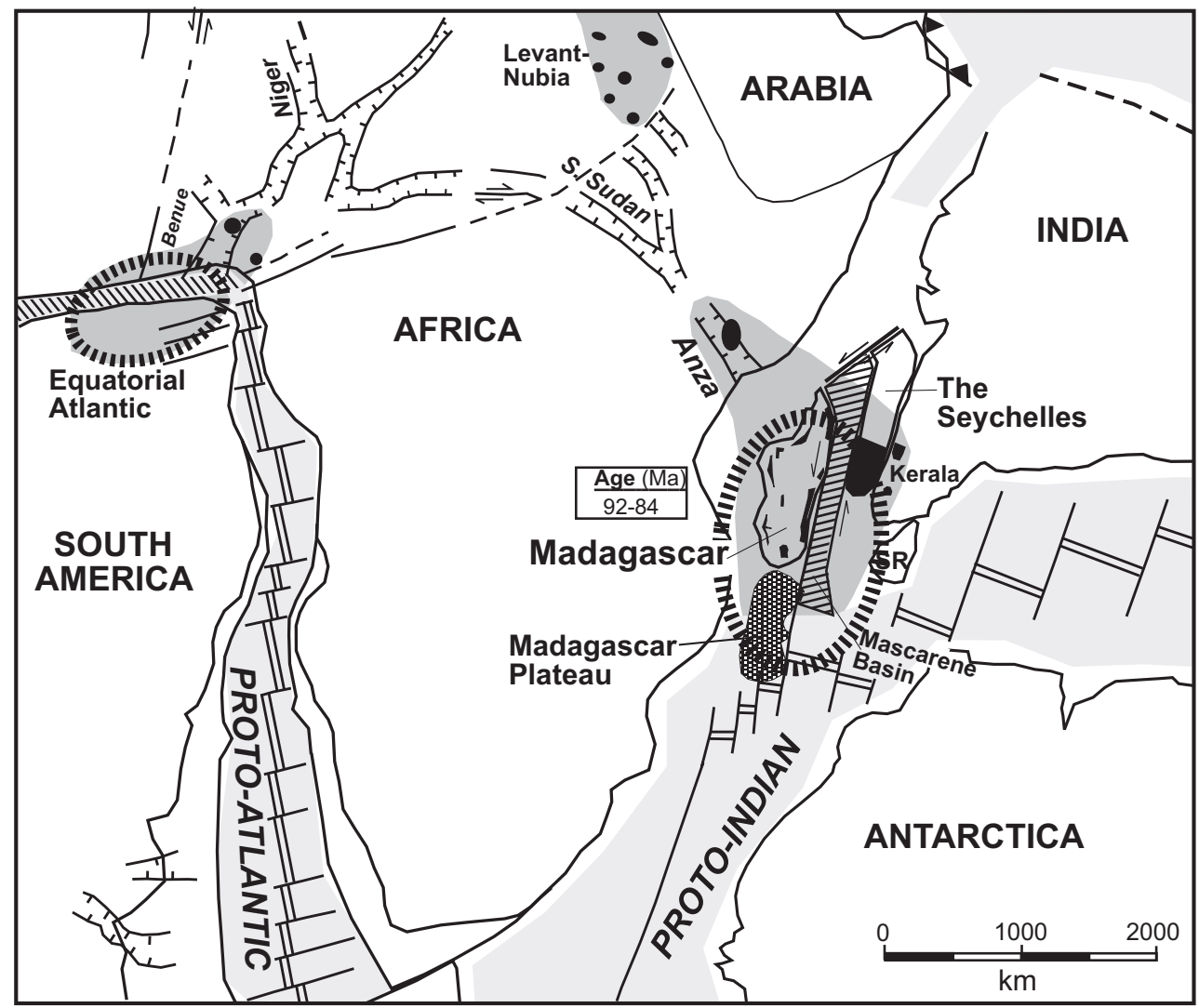

Fig. 8. Tectonic setting of central Gondwana in the Late Cretaceous time (mainly after Dyment, 1991; Storey 1995, and Plummer, 1996) showing the Madagascar igneous and plume province, and the breakup between Madagascar and The Seychelles. For sources of distribution of magmatism, location of plume head and geochronology, see text.

lites) that intruded the East Antarctic and northeastern Indian grabens (Fig. 6). The basaltic volcanism was determined $\left({ }^{40} \mathrm{Ar} /{ }^{39} \mathrm{Ar}\right.$, and paleomagnetic evidence) by Sakai et al. (1997) to be 126-130 Ma, although Baksi (1995) interprets his ${ }^{40} \mathrm{Ar} /{ }^{39} \mathrm{Ar}$ dates at around $117 \mathrm{Ma}$. These volcanics formed seaward dipping flows largely buried beneath a sedimentary cover in the Bengal basin (Rajmahal) (Kent, 1991) and the large Kerguelen oceanic plateau (Frey et al., 2000). The Kerguelen plateau basalts comprise an oceanic plateau which filled the space between India and Antarctica after the continental breakup and initial drifting at $\approx 110 \mathrm{Ma}$ (reviewed by Frey et al., 2000).

Because of the scarcity of identifiable magnetic anomalies between India and Antarctica, the exact age of the onset of the ridge in this area cannot be determined more precisely than 118-128 m.y. (Lawver et al., 1991, 1992). The geochronological evidence shows that the timing of the predominantly Kerguelen-Rajmahal magmatism (126-110 Ma) is too young for it to have been involved in the initial breakup of this margin $\sim 130 \mathrm{Ma}$ (Storey, 1995).

\subsection{The Late Cretaceous Madagascar province}

The Upper Cretaceous widespread igneous rocks of Madagascar are exposed along the $1500 \mathrm{~km}$ length of the east coast, which marks a rifted margin, and in basins in western Madagascar (Fig. 8). This igneous sequence consists of basalt flows and dikes, some rhyolite flows and small gabbroic plutons (Storey et al., 1995). The Madagascar flood volcanics and the associated oceanic plateaus constitute a single igneous province (Coffin and Eldholm, 1994), with an area of more than $1 \times 10^{6} \mathrm{~km}^{2}$ (Storey et al., 1995), which related to the Marion mantle plume (Storey, 1995).

Reliable ${ }^{40} \mathrm{Ar} /{ }^{39} \mathrm{Ar}$ measurements of magmatic rocks from Madagascar yielded ages between $90.7 \pm 0.6$ and 83.6 $\pm 1.6 \mathrm{Ma}$ (Storey et al., 1995; Torsvik et al., 1998), as well as a weighted mean ${ }^{206} \mathrm{~Pb} /{ }^{238} \mathrm{U}$ zircon-baddeleyite age of 91.6 $\pm 0.3 \mathrm{Ma}$, which marks the initiation of this magmatic event. These ages are concordant with the stratigraphic evidence in Madagascar and demonstrates a magmatic event that lasting 8 m.y. Equivalent conjugate basaltic volcanism is reported from the southern part of the Seychelles microcontinent (Plummer and Belle, 1995), and gabbroic and felsic dike intrusions in southwest India (central and north Kerala) yielded ${ }^{40} \mathrm{Ar} /{ }^{39} \mathrm{Ar}$ ages at about $85 \mathrm{Ma}$ (Radhakrishna et al., 1999). The rifting between Madagascar and SeychellesIndia and the opening of the Mascarene basin took place after significant strike-slip faulting (Dyment, 1991; Plummer and Belle, 1995; Plummer, 1996). Sea-floor spreading in the Mascarene basin started at about $80 \mathrm{Ma}$ (magnetic anomaly 
C33; White and McKenzie, 1989) and ceased after $63 \mathrm{Ma}$ (C28), when the spreading moved to the newly formed rift between the Seychelles and India (see below).

\subsection{The Latest Cretaceous-Tertiary Deccan - Seychelles province}

The Deccan Traps, which have an areal extent of 1.5 million $\mathrm{km}^{2}$ over western India (Baksi, 1994), are well known continental tholeiitic flood basalts (Fig. 9). Much geochronological and paleomagnetic efforts (Courtillot et al., 1986, 1988; Féraud and Courtillot, 1994, Hofmann, 1997) have been made to constrain the time interval of the main volcanic outpouring to no more than $1 \mathrm{Ma}$ and to prove its temporal coincidence with the K-T boundary. Several ${ }^{40} \mathrm{Ar} /{ }^{39} \mathrm{Ar}$ geochronological studies of the $\sim 2000 \mathrm{~m}$ basaltic section yielded various age ranges: 68.5-66.7 Ma (Duncan and Pyle, 1988), 69-65 Ma (Courtillot et al., 1988); 67-62.5 Ma (Venkatesan et al., 1993). Basu et al. (1993) studied several alkaline igneous complexes within the basaltic province and their ${ }^{40} \mathrm{Ar} /{ }^{39} \mathrm{Ar}$ dates of biotite separates range between $68.5 \mathrm{Ma}$ and 65 Ma. The above-mentioned results suggest that the main Deccan event lasted between 68.5 and $65 \mathrm{Ma}$ (about 3.5 m.y.). In the north Karela area, southwest India, the subalkaline tholeiitic dolerite dike swarms, belonging to the Deccan event, yielded a larger range of plateau ages between 70 and $61 \mathrm{Ma}$ (Radhakrishna et al., 1999). Synchronously, there was volcanic activity on the central and northern continental Seychelles, which were than connected to "Greater India" (Fig. 9) (Plummer and Belle, 1995; Plummer, 1996). The age of this magmatism in the Seychelles has been reported as: $66 \mathrm{Ma}$ (K/Ar, Croxton et al., 1981); $64 \mathrm{Ma}$ $\left({ }^{40} \mathrm{Ar} /{ }^{39} \mathrm{Ar}\right.$, Duncan and Hargraves, 1990$) ; 63 \mathrm{Ma}(\mathrm{Rb} / \mathrm{Sr}$ isochron, Dickin et al., 1986).

Early rifting in the central Deccan province (Fig. 9) presumably occurred between the Seychelles and India (Plummer and Belle, 1995) and along the Gop, Narmada-Son (Courtillot et al., 1999) and maybe the Koyana and Cambay rifts (Basu, et al., 1993). The successful breakup and initiation of oceanic crust, $\sim 65 \mathrm{Ma}$ (slightly older than C28), took place along the western coast of India, where the Central Indian seafloor spreading ridge was formed after jumping from the Mascarene ridge which ceased spreading.

\subsection{The Tertiary-Recent Afar province}

The Afar plume impinged the base of the African stable and cool (Zeyen et al., 1997) lithosphere below Kenya and south Ethiopia (Fig. 10) in the Eocene, when the East African rift area started to uplift followed by initial and scarce volcanic eruptions between ca. 40 and 34 Ma (Ebinger et al., 1993; George et al., 1998). After some northward propagation, the dominant volcanic outpouring in Ethiopia and Yemen formed typical flood volcanism (CFV), lasting between 31 and $28 \mathrm{Ma}$ (Baker et al., 1996; Hofmann et al., 1997), although the whole magmatic event continued until $19 \mathrm{Ma}$ with varying intensities. Two distinct pulses of uplift and rift-

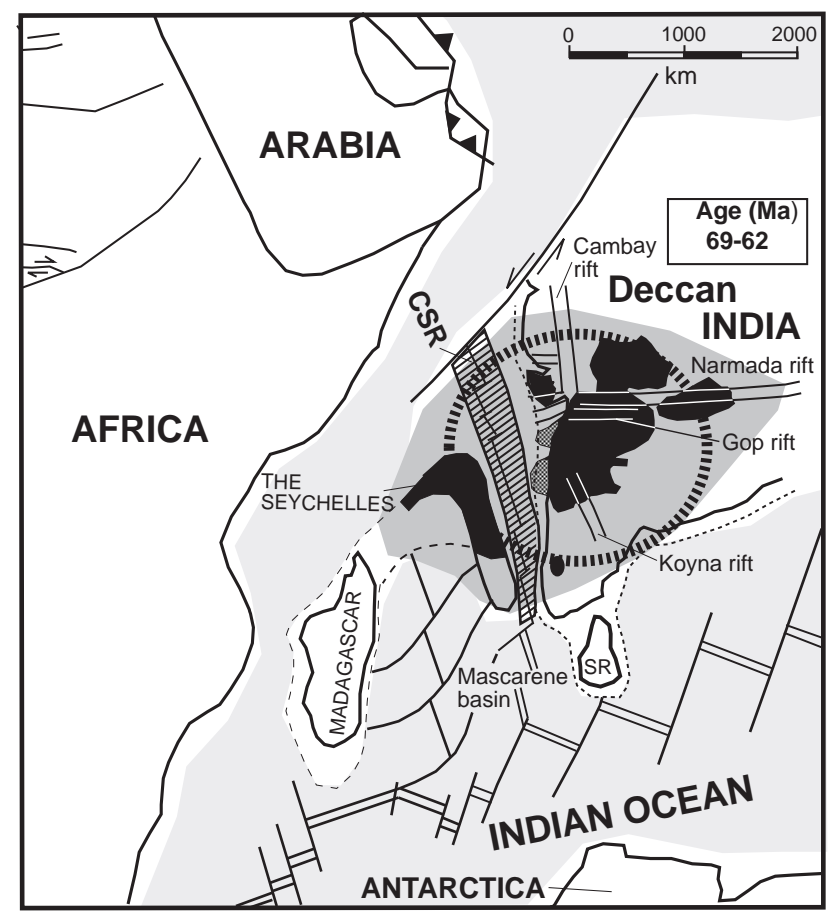

Fig. 9. Tectonic setting of East African, Arabian and Indian plates in the Tertiary time (mainly after Basu et al., 1993; Plummer and Belle, 1995, Plummer, 1996, and Courtillot et al., 1999), showing the Deccan igneous and plume province, and the breakup between the Seychelles and India. For sources of distribution of magmatism, location of plume head and geochronology, see text. SR - Sri Lanka; CSR - Carlsberg ridge.

ing have been suggested by Omar and Steckler (1995), the first anywhere from 30 to $35 \mathrm{Ma}$ (Courtillot et al., 1999), and the second between 20 and $25 \mathrm{Ma}$. These extensional tectonics caused updoming, with the center above the plume (Fig. 3), and rifting parallel to extensional stress in the lithospheric mantle (Zeyen et al., 1997). True seafloor spreading in the Red Sea rift initiated later than $\sim 20 \mathrm{Ma}$ (Courtillot et al., 1999), whereas the magmatism over the whole Afar igneous province continued in two more cycles (ca. 16-11 and 6-0 Ma) up to recent time (Segev, 2000a). Although the Afar province has been active for more than ca. 40 m.y., the newly formed Red Sea and Gulf of Aden oceanic basins are relatively narrow, as a result of regional plate tectonic constraints.

\section{Discussion and conclusions}

Two main lines of factual data are used in this study: (1) Surface and sub-marine geology - the distribution of igneous provinces, mainly flood basalts and oceanic plateaus, that took part in the Gondwanan lithospheric breakup process; and (2) Geochronology - up-to-date reliable chronology of magmatic events in each of the described igneous provinces.

The synthesis of geological and geochronological evidence dealing with the spatial (Fig. 11) and temporal 


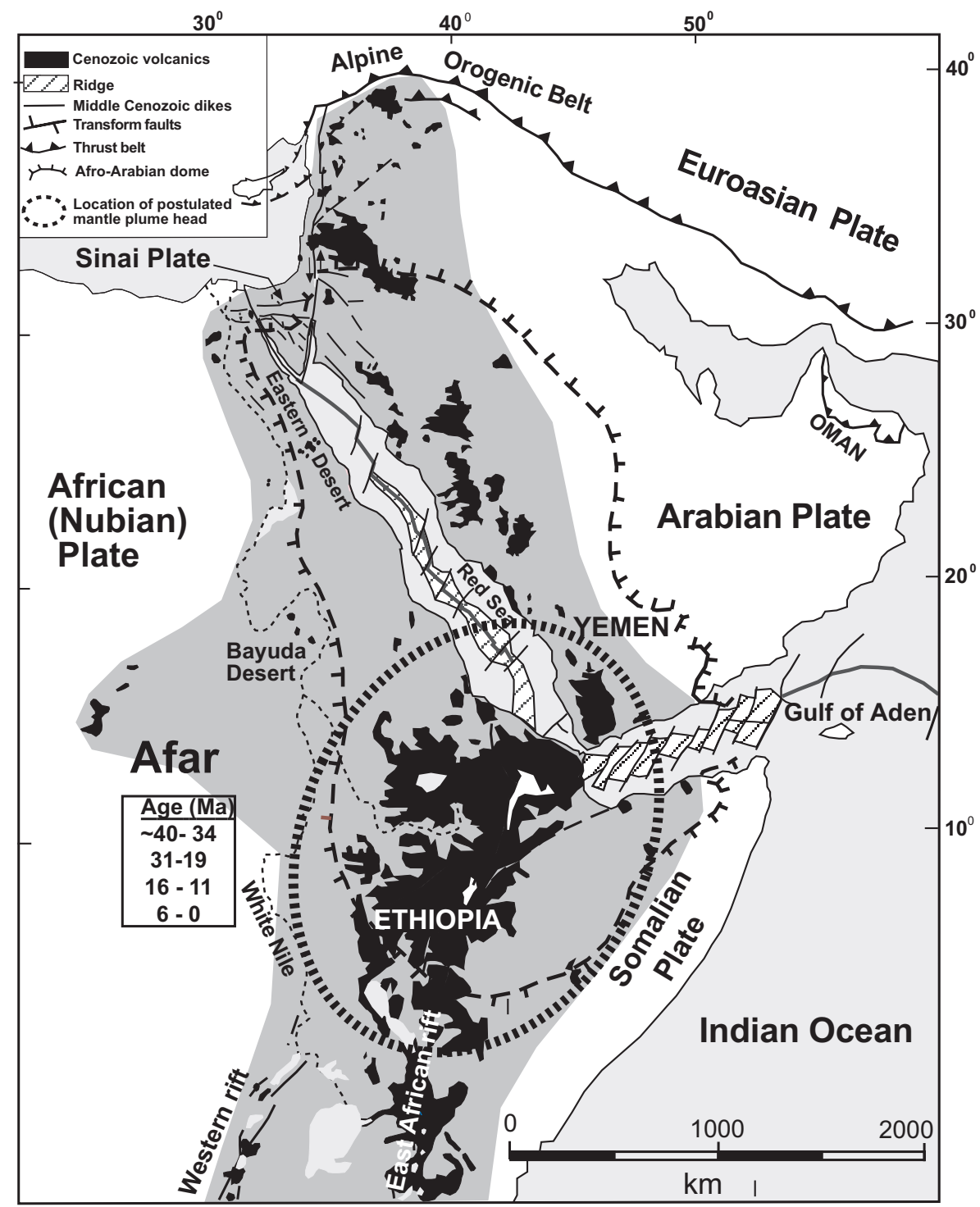

Fig. 10. Tectonic setting of East African and Arabian plates in the Recent time (mainly after Davison et al., 1994 and Baker, et al., 1996), showing the Afar igneous and plume province, and the breakup between Africa and Arabia. For sources of distribution of magmatism, location of plume head and geochronology, see text.

(Fig. 12) distribution of igneous provinces, associated by domal uplift, rifting and breakup of the continental lithosphere of Pangaea and later on Gondwana, adopted the mantle plume theory as the principal cause for these phenomena (e.g. Storey, 1995; Courtillot et al., 1999; Segev, 2000a).

The plate reconstruction, which was made by several researchers using geophysical evidence, presented here schematically for better understanding the consequence of each plume and for display the different tectonic setting where the later plume was acted. The relationships between the plume provinces and the plate motions are beyond the scope of the present paper.

\section{Initiation of first generation plumes}

Since the assembly of Pangaea during Permo-Carboniferous times, three plume provinces marks the first generation of powerful lower mantle upwelling plumes (Figs. 11, 12):

1. The Permo-Carboniferous European-northwestern Africa plume, which started the breakup of the Pangaea supercontinent into the northern Euroasia and the southern Gondwana fragments. This plume emplaced close to the center of Pangaea (Doblas et al., 1998) and close to the Carboniferous Variscan orogen.

2. The Jurassic Karoo plume, which was located north of the Pacific (southern Gondwana) subduction belt, caused the breakup between east and west Gondwana. 

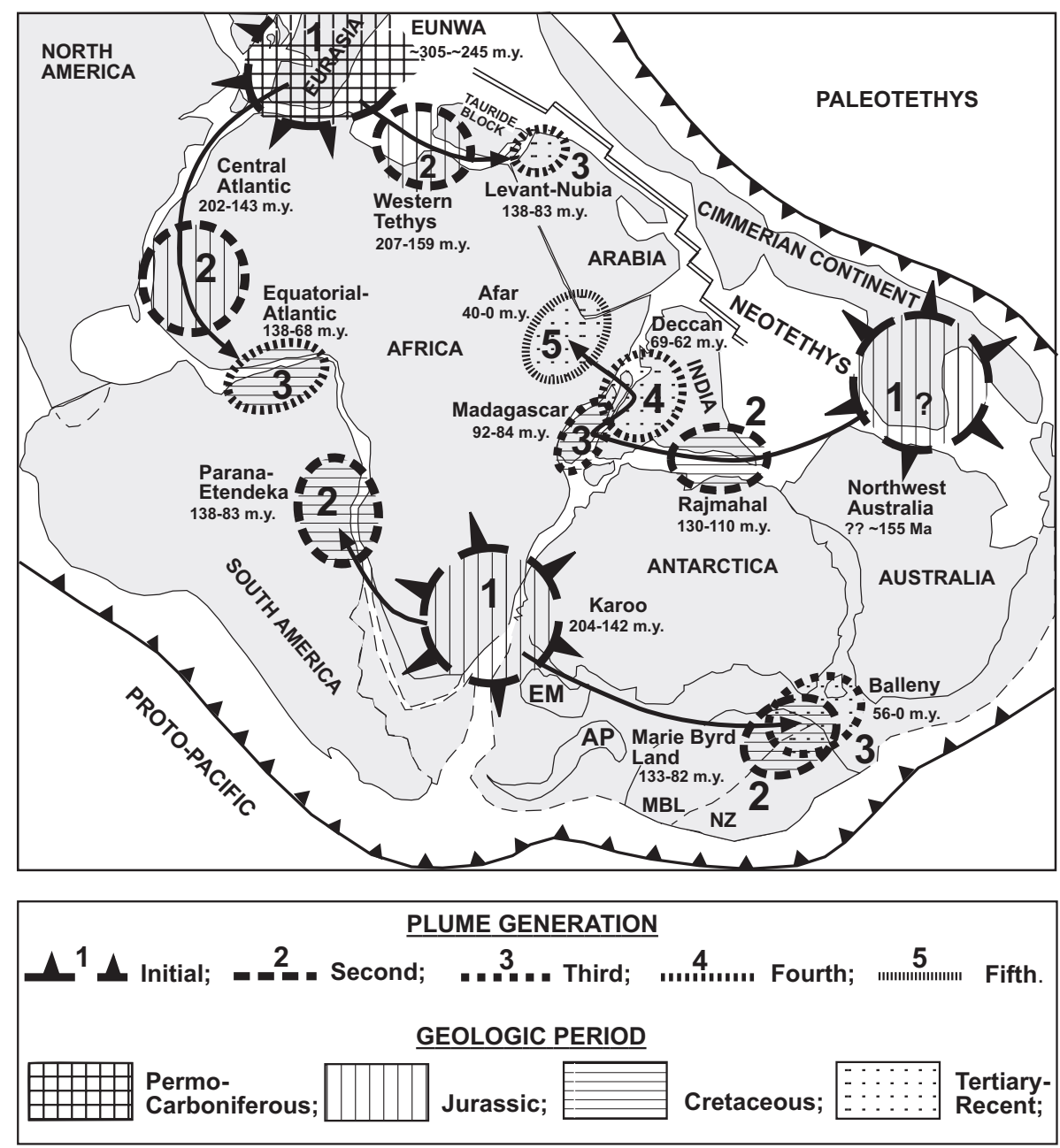

Fig. 11. Plume provinces throughout Gondwana supercontinent (Gondwana reconstruction modified mainly after Lawver et al., 1992). The different lines and the numbers mark the various plume generations.

3. The Jurassic northwestern Australia plume, emplaced close to the active margins of the southeast Neotethys, initiated the opening of the Indian Ocean.

The above mentioned plumes are closely associated with convergent environments, one orogen and two subduction zones. Therefore, they indicate a cogenetic relationships between initial plumes and convergence, or actually to the downwelling lithospheric slabs.

Although each of these plumes met different lithospheres (orogen - EUNWA, craton - Karoo, and plate margins - NW Australia), the consequential large quantities of melts, lithospheric rifting, breakup and formation of oceanic spreading center typify them all.

As shown by seismic structure of slabs, the subducting plates cross the $660 \mathrm{~km}$ discontinuity and sink down toward the core mantle boundary (CMB) (van der Hilst and Seno, 1993; van der Hilst et al., 1997; Bijwaard and Spakman, 1998). Such a process causes significant instability at the $660 \mathrm{~km}$ depth seismic discontinuity and also close to the CMB. Models of convection showed that new plumes might form as a result of boundary layer instabilities (Whitehead and Chen, 1970; Dubuffet et al., 2000).

\section{Plume migration}

\subsection{The detachment of Gondwana from Pangaea}

The Permo-Carboniferous ( 320-275 m.y.) EUNWA plume activity in central Pangaea (Doblas et al., 1998) preceded led to the opening of the Permo-Triassic Neotethys (Fig. 2), and to intensive rifting in northern Europe and toward the Central Atlantic and the Levant areas (Ziegler, 1990; Guiraud, 1998; Segev, 2000b). After a few tens of million of years, two nearly synchronous adjacent Jurassic plumes developed toward the Central Atlantic (southwestern path) and the Western Tethys (southeastern path; Figs. 11, 12). The spatial overlapping between the EUNWA plume and the newly formed Jurassic plumes, as well as their periodic age progression, connect these plumes to the same genetic process of uprising lower mantle material. These second-generation plumes 


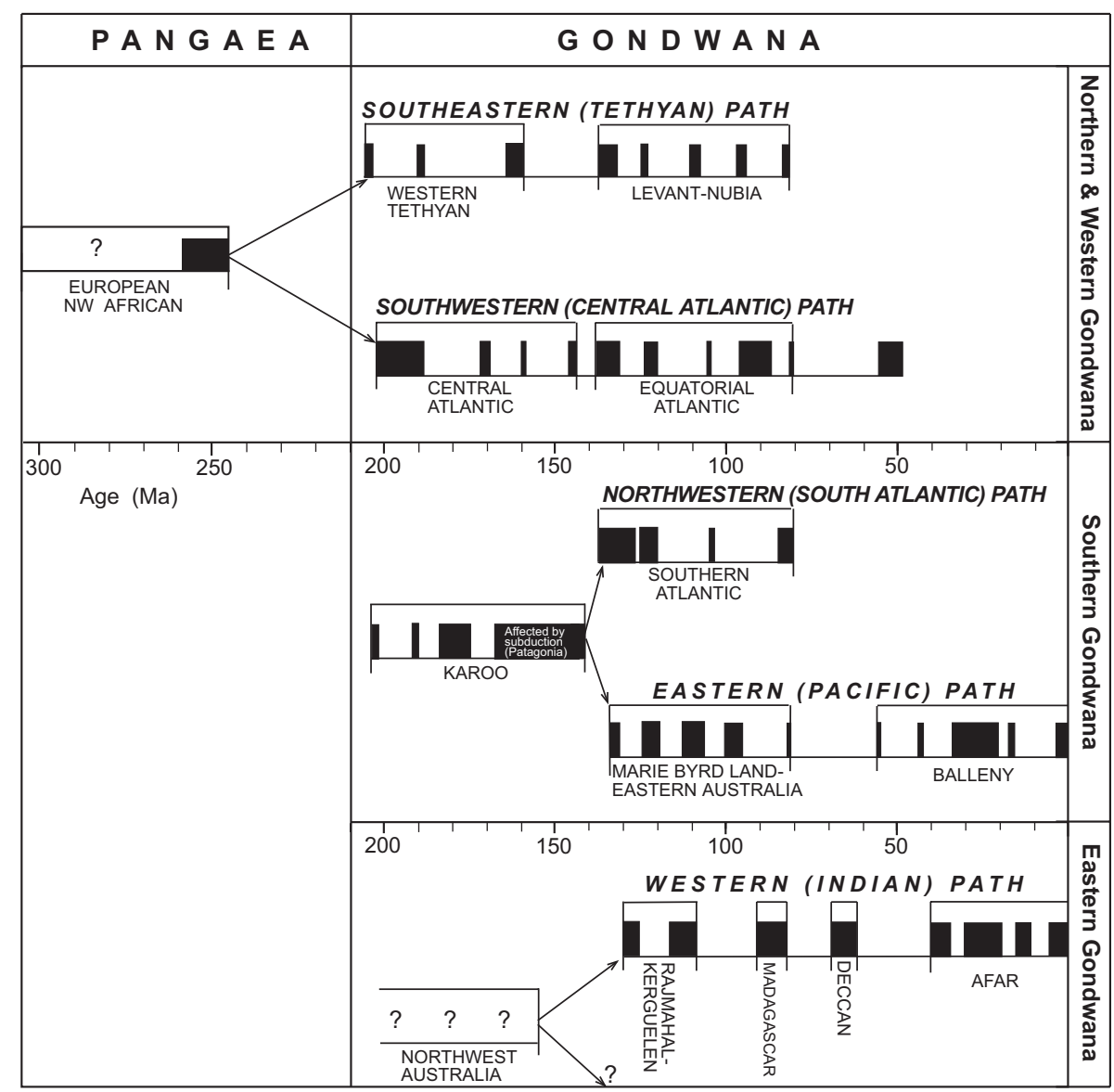

Fig. 12. The temporal migration of magmatic events caused by plume activity (modified after Segev, 2000a).

caused the complete detachment of Gondwana from Eurasia, and mark the development of two migrating lower mantle upwelling flows (the plume activities within the latter supercontinent were not included in the present study).

Newly formed third-generation Cretaceous plumes, Equatorial Atlantic on the southwest path (138-68 m.y.) and the Levant-Nubia (138-83 m.y.), on the southeast path, occurred with the same trend in each of these paths. The latter ceased abruptly in the Late Cretaceous as a result of change in the plate tectonic configuration, whereas the magmatic activity in the Equatorial Atlantic ceased progressively in the Tertiary. Whereas the magmatism in the Equatorial Atlantic started in the latest Jurassic and periodically acted synchronously with the Paraná-Etendeka province, the area remains closed until 119-120 Ma.

\subsection{The break-up of Gondwana to east and west sectors and their southern dispersal}

Similar to northern Gondwana, the evolutionary scenario of the Jurassic ( 204-142 m.y.) the Karoo initial plume, which caused the breakup between east and west Gondwana along the proto-oceanic rift between the Weddel Sea and Somali basin (Fig. 5), developed in southern Gondwana. A minor rifting phase from the southernmost tip of the South Atlantic up to the vicinity of the Salado Basin in South America, started close to the end of the Karoo province (Nürnberg and Müller, 1991). Although the trend of the main continental breakup was SSW-NNE, the dispersal of the magmatism toward Patagonia (South America) and Victoria (SE Australia) took place along a nearly normal trend, sub-parallel to the Pacific subduction zone.

After the Karoo plume activity, two adjacent Cretaceous second-generation offshoot plumes developed on two opposite edges along the WNW (Paraná-Etendeka) - ESE (Marie Byrd Land-East Australia) direction (Figs. 11, 12). The Paraná-Etendeka plume (138-83 m.y.), which is a wellstudied feature (Renne et al., 1999), caused the breakup between Africa and South America (Fig. 4), and the Marie Byrd Land-East Australia plume (133-82 m.y.), caused the breakup between Antarctica and New Zealand and the opening of the Tasman Sea (Storey et al., 1999; Fig. 6). The latter had an overlapping Tertiary-Recent third generation plume (Balleny) that changed the tectonic setting of the previous plume. In the Paraná-Etendeka province, the magmatism continued up to $83 \mathrm{Ma}$ in volcanic fields (Alto Paranaiba) and various igneous intrusions surrounding the Paraná basin (Gibson et al., 1995). Africa and South America are assumed by Nürnberg and Müller (1991) to have been rigidly 
attached until magnetic Chron M4 (ca. 127 Ma), and between this Chron and Chron M0 (118.7 Ma) the rifting propagated northward into the Benue Trough. Evidence is lacking for younger third plume evolution (updoming, new rifting, changing of extensional directions and continental breakup) in both parts of this province. In the Paraná area, intrusions of dikes until 70 Ma have been reported (Deckart et al., 1998), and alkaline magmatism in eastern Paraguay is known until the Tertiary (Comin-Chiaramonti et al., 1999). Furthermore, Tertiary oceanic islands magmatism in the southern Atlantic Ocean (Trindad-Vitoria, Walvis ridge and Rio Grande rise) represents a major phase of late-stage alkaline volcanism that followed the main plume activity. This evidence, as well as the arguments about a recently existing fossil plume beneath the Paraná basin (VanDecar et al., 1995), point to a progressive decay (lasting $\sim 80$ m.y.) of the Paraná-Etendeka plume.

\subsection{The dispersal of the northern part of east Gondwana -} the Indian path

The Jurassic igneous province of northwest Australia is poorly defined since it includes either poorly accessible continental margins and oceanic plateaus (Rowley Terrace-Scott plateau and Exmouth plateau), or subducted lithospheric fragments toward the north. The present evidence indicates intensive magmatism, extension, rifting and breakup of this area (Powell et al., 1988; Mutter et al., 1989, Veevers et al., 1991). The final magmatism of this first-generation plume (White and McKenzie, 1989) is dated about $155 \mathrm{Ma}$, and its possible expansion toward the Pacific (exterior Gondwana) is not included in the present study. The second generation Early Cretaceous plume (Rajmahal-Kerguelen) migrated southeastward toward the area between India and the stillattached Australia and Antarctica (Fig. 6). At this new position it first produced the Wallaby and Naturaliste plateaus (Crawford and von Rad, 1994), as well as the better defined Bunbury basalt ( $130 \pm 0.5$, Pringle et al., 1994), which is the oldest rock studied. The limited access to the lower parts of these oceanic plateaus, as well as to the Kerguelen plateau, prohibited measuring their initiation. The contemporaneous initiation of seafloor spreading off the western Australian margin (Powell et al., 1988) indicates an earlier beginning of magmatism. The age herein predicted is $\sim 138 \mathrm{Ma}$, which is the synchronous magmatic event that initiated the South Atlantic, Equatorial Atlantic, Levant-Nubia and Marie Byrd Land-East Australia igneous provinces (Segev, 2000a). The main basaltic outpouring along the boundary between India and Antarctica (Rajmahal, Bengal basin and Kerguelen) took place between 117 and $109 \mathrm{Ma}$ (reviewed by Segev, 2000a) alongside the development of the oceanic spreading center (Gopala Rao and Krishna, 1997). Oceanic island magmatism in the eastern Indian Ocean (Ninetyeast and Broken Ridges), that represents the late-stage alkaline volcanism after the main plume activity, continued up to Tertiary times.

A third generation plume along the same westward trend produced large quantities of melts in Madagascar, Madagascar plateau and the Seychelles area (Fig. 8) since $92 \mathrm{Ma}$.
These evidence points to relatively rapid migration (about 40 m.y.) and reactivation of this lower mantle current that jumped northeastward, for its fourth time, below western India and the Seychelles some 24 m.y. later (lasted 69-62 m.y.). The reason for treating each of these plumes separately is the complete evolutionary sequence that they produced, from updoming through flood basalts, breakup and opening of new spreading ridge. The fifth, and the last, generation of this rapidly migrating current is the Afar plume, which started at $40 \mathrm{Ma}$ and continues to the present.

The position of these plumes relative to the African plate (Fig. 11) demonstrates a swarm of close plumes that migrated predominantly along the same westward trend.

To sum up: The initial plumes, the better known EUNWA and the Karoo, as well as the lesser known Northwest Australia, differ from the others by their larger diameter ( $\sim 3000 \mathrm{~km}$ compared to about $2000 \mathrm{~km}$ ) and the apparently radial dispersion of magmatism and rifting, although they all have only a single spreading system along their main rift. The formation of such a spreading system in all the studied plumes of Gondwana strengthens the view that they led to a newly established extensional regime caused by the divergent upper mantle circulation (Segev, 2000a). This interpretation does not negate the existence of "passive rifts" that are not connected directly to mantle plumes. For example, the Southeast Indian Ridge between southern Australia and Antarctica may represent such a case, although it might have been strongly influenced by the Balleny plume activity.

Comparison between the studied plumes and their paths emphasizes the exceptional behavior of the Indian plume swarm where part of the magmatic events (Madagascar and Deccan), which lasted ca. 8 m.y., represents an entire plume evolution (Fig. 12). Moreover, this is the only path where the migrating current significantly changed course from the main trend (Fig. 11). The short-lasting and relatively close plume swarm may point to a similar deep (Lower mantle) source, and the change in course might have occurred because of an interruption of a deep northeastward weak flow. The recurring consequential breakup and formation of spreading centers along the Indian path is indicative of migration below the upper mantle circulation, leading later to divergent circulation in it and lithospheric breakup. The findings of the present study emphasize a spatial difference between the plume province and the wider, igneous province; the latter is generally about three times greater along its extended axis than that of the plume province. A well-exposed example is the Afar plume province (Fig. 10) of ca. $2000 \mathrm{~km}$ compared to the ca. $6000 \mathrm{~km}$ igneous province. The Afar plume head is defined as the fifth plume generation along the Indian path and, as suggested above, it migrated within the lower mantle. The large northward volcanic fields (Harrats), mainly along the western margin of the Arabian plate, and the southward volcanism along the Western and Eastern African rifts, which are a continuous dispersion of the volcanic activity outward from the plume province, probably represent the sub-lithospheric migration of the Afar plume. 
Acknowledgements. The paper benefited from discussions and the review of M. Abelson (Geological Survey of Israel) and was improved by the comments of P. A. Ziegler, L. Michon and an anonymous reviewer. B. Katz edited the manuscript.

\section{References}

Allen, C. M., Wooden, J. L., and Chappel, B. W.: Late Paleozoic crustal history of central coastal Queensland interpreted from geochemistry of Mesozoic plutons: The effects of continental rifting, Lithos, 42, 67-88, 1997.

Allen, C. M., Williams, I. S., Stephens, C. J., and Fielding, C. R.: Granite genesis and basin formation in an extensional setting: the magmatic history of the northernmost New England Orogen, Aust. J. Earth Sci., 45, 875-888, 1998.

Allsopp, H. L. and Barrett, D. R.: Rb-Sr age determinations of South African kimberlite pipes, in: Ahrens, L. H., Dawson, J. B., Duncan, A. R., and Erlank, A. J. (Eds): Physics and Chemistry of the Earth, 9, 605 p., 1975.

Allsopp, H. L., Manton, W. I., Bristow, J. W., and Erlank, A. J.: $\mathrm{Rb}-\mathrm{Sr}$ geochronology of Karoo felsic volcanics, in: Erlank, A. J. (Ed.): Petrogenesis of the volcanic rocks of the Karoo Province, Spec. Publ. Geol. Soc. S. Afr., 13, 273-280, 1984.

Allsopp, H. L. and Roddick, J. C.: Rb-Sr and ${ }^{40} \mathrm{Ar}-{ }^{39} \mathrm{Ar}$ age determination on phlogopite micas from the pre Lebombo Group Dokolwayo kimberlite pipe, Spec. Publ. Geol. Soc. S. Afr., 13, 267-271, 1984.

Alric, V. I., Haller, M. J., Féraud, G., Bertrand, H., and Zubia, M.: Cronología ${ }^{40} \mathrm{Ar} /{ }^{39} \mathrm{Ar}$ del vulcanismo jurásico de la Patagonian extraandina, Actas del XIII Congreso Geológico Argentino, Buenos Aires, Tomo, 5, 243-250, 1996.

Anderson, D. L.: Superplumes or supercontinents? Geology, 22, 39-42, 1994a.

Anderson, D. L.: The sublithospheric mantle as the source of continental flood basalts; the case against the continental lithosphere and plume head reservoirs, Earth Plan. Sci. Lett., 123, 269-280, 1994b.

Asmus, H. E. and Baisch, P. R.: Geological evolution of the Brazilian continental margin, Episodes, 4, 3-9, 1983.

Baer, G., Heimann, A., Eshet, Y., Weinberger, R., Mussett, A., and Sherwood, G.: The Saharonim basalt: A Late Triassic - Early Jurassic intrusion in southeastern Makhtesh Ramon, Israel, Isr. J. Earth Sci., 44, 1-10, 1995.

Baker, J., Snee, L., and Menzies, M.: A brief Oligocene period of flood volcanism in Yemen: Implication for the duration and rate of continental flood volcanism at the Afro-Arabian triple junction, Earth Plan. Sci. Lett., 138, 39-55, 1996.

Baksi, A. K.: Geochronological studies on whole-rock basalts, Deccan Traps, India: Evaluation of the timing of volcanism relative to the K-T boundary, Earth Plan. Sci. Lett., 121, 43-56, 1994.

Baksi A. K.: Petrogenesis and timing of volcanism in the Rajmahal flood basalt province, northeastern India, Chem. Geol., 121, 7390, 1995.

Baksi, A. K. and Archibald, D. A.: Mesozoic igneous activity in the Maranhão province, northern Brazil: ${ }^{40} \mathrm{Ar} /{ }^{39} \mathrm{Ar}$ evidence for separate episodes of basaltic magmatism, Earth Plan. Sci. Lett., 151, 139-153, 1997.

Basu, A. R., Renne, P. R., DasGupta, D. K., Teichmann, F., and Poreda, R. J.: Early and late alkali igneous pulses and a high-3He plume origin for the Deccan flood basalts, Science, 261, 902905, 1993.
Behrendt, J. C., LeMasurier, W. E., and Cooper, A. K.: The West Antarctic rift system - a propagating rift "captured" by mantle plume, in: Yoshida, Y., Kaminuma, K., and Shirashi, K. (Eds.): Recent progress in Antarctic Earth Science, Terra Scientific Publishing Comp. (TERRAPUB), Tokyo, 315-322, 1992.

Behrendt, J. C., Blankenship, D. D., Finn, C. A., Bell, R. E., Sweeney, R. E., Hodge, S. M., and Brozena, J. M.: CASERTZ aeromagnetic data reveal late Cenozoic flood basalts (?) in the West Antarctic rift system, Geology, 22, 527-530, 1994.

Bijwaard, H. and Spakman, W.: Closing the gap between regional and global travel time tomography, J. Geophys. Res., 103, 30 055-30 078, 1998.

Bott, M. H. P.: The stress regime associated with continental breakup, in: Storey, B. C., Alabaster, T., and Pankhurst, R. J. (Eds.): Magmatism and the causes of continental break-up, Geol. Soc. Spec. Publ., 68, 125-136, 1992.

Brewer, T. S., Rex, D., Guise, P. G., and Hawkesworth, C. J.: Geochronology of Mesozoic tholeiitic magmatism in Antarctica: Implication for the development of the failed Weddell Sea rift system, in: Storey, B. C., King, E. C., and Livermore, R. A. (Eds): Weddell Sea tectonics and Gondwana breakup, Spec. Publ. Geol. Soc. Lond., 108, 45-61, 1996.

Bryan, S. E., Constantine, A. E., Stephens, C. J., Ewart, A., Schön, R. W., and Parianos, J.: Early Cretaceous volcano-sedimentary successions along the eastern Australian continental margin: Implications for the break-up of eastern Gondwana, Earth Plan. Sci. Lett., 153, 85-102, 1997.

Burg, J. P., van den Driessche, J., and Brun, J. P.: Syn- to postthickening extension in the Variscan Belt of Western Europe: Modes and structural consequences, Geol. Fr., 3, 33-51, 1994.

Cahen, L., Snelling, N. J., Delhal, J., Bonhomme, M., and Ledent, D.: The Geochronology and Evolution of Africa, Clarendon Press, Oxford, 1984.

Campbell, I. H. and Griffiths, R. W.: Implications of mantle plume structure for the evolution of flood basalts, Earth Plan. Sci. Lett., 99, 79-93, 1990.

Cloos, H.: Conversation with the Earth, Routledge and Kegan Paul, London, 1954.

Coffin, M. F. and Eldholm, O.: Large igneous provinces: Crustal structure, dimensions, and external consequences, Rev. Geophys., 32, 1-36, 1994.

Colvell, J. B., Symonds, P. A., and Crawford, A. J.: AGSO, J. Austr. Geol. Geophys., 15, 137-156, 1994.

Comin-Chiaramonti, P., Cunari, A., DeGraff, J. M., Gomes, C. B., and Piccirillo, E. M.: Early Cretaceous-Tertiary magmatism in Eastern Paraguay (western Paraná basin): geological, geophysical and geochemical relationships, J. Geodynamics, 28, 375391, 1999.

Conway, B. H.: Paleozoic-Mesozoic Palynology of Israel. II: Palynostratigraphy of the Jurassic succession in the subsurface of Israel, Isr. Geol. Surv. Bull., 82, 1-39, 18 pl, 1990s.

Courtillot, V., Besse, J., Vandamme, D., Montigny, R., Jaeger, J. J., and Cappetta, H.: Deccan flood basalts at the Cretaceous/Tertiary boundary? Earth Plan. Sci. Lett., 80, 361-374, 1986.

Courtillot, V., Féraud, G., Maluski, H., Vandamme, D., Moreau, M. G., and Besse, J.: Deccan flood basalts and the Cretaceous/Tertiary boundary, Nature, 333, 843-846, 1988.

Courtillot, V., Jaupart, C., Manighetti, I., Tapponnier, P., and Besse, J.: On the causal links between flood basalts and continental breakup, Earth Plan. Sci. Lett., 166, 177-195, 1999.

Cox, K. G.: The Karoo province, in: Macdougall, J. D. (Ed.): Continental flood basalts, Kluwer, Dordrecht, 239-271., 1988 
Cox, K. G.: The role of mantle plumes in the development of continental drainage patterns, Nature, 342, 873-877, 1989.

Crawford, A. J. and von Rad, U.: The petrology, geochemistry and implication of basalts dredged from the Rowley Terrace-Scott Plateau and Exmouth Plateau margins, northwestern Australia, AGSO J. Austr. Geol. and Geophys., 15(1), 43-54, 1994.

Croxton, C. A., Hitchings, V. H., and Marshall, P. R.: The biostratigraphy and palaeoenvironments of the interval 1400'-12790', with petrography, X-ray diffraction and Potassium/Argon age dating of selected samples, from the Amoco Seychelles Petroleum Co. Rieth Bank-1 well, offshore Seychelles, Robertson Res. Intl. Rep., 2636 p/F, 61, 1981.

Dallmeyer, R. D., Franke, W., and Weber, K.: Pre-Permian Geology of central and Eastern Europe, Springer-Verlag, New York, 604 pp, 1995.

Davey, B. and Wood, R.: Gravity modelling of the Hikurangi Plateau, Marine Geol., 118, 139-151, 1994.

Davison, I., Al-Kadasi, M., Al-Khirbash, S. et al.: Geological evolution of the south-eastern Red Sea rift margin, Republic of Yemen, Bull. Geol. Soc. Am., 106, 1474-1493, 1994.

Deckart, K., Féraud, G., and Bertrand, H.: Age of Jurassic continental tholeiites of French Guyana, Surinam and Guinea: Implications for the initial opening of the Central Atlantic Ocean, Earth Plan. Sci. Lett., 150, 205-220, 1997.

Deckart, K., Féraud, G., Marques, L. S., and Bertrand, H.: New time constraints on dyke swarms related to the Paraná - Etendeka magmatic province, and subsequent South Atlantic opening, southeastern Brazil, J. Volcan. Geotherm. Res., 80, 67-83, 1998.

Dewey, J. F.: Extensional collapse of orogens, Tectonics, 7, 11231139, 1988

Dickin, A. P., Fallick, A. E., Halliday, A. N., Macintyre, R. M., and Stephens, W. E.: An isotopic and geochronological study of the younger igneous rocks of the Seychelles, Earth Plan. Sci. Lett., 81, 46-56, 1986.

Doblas, M., Oyarzun, R., López-Ruiz, J., Cebriá, J. M., Youbi, N., Mahecha, V., Lago, M., Pocovi, A., and Cabanis, B.: PermoCarboniferous volcanism in Europe and northwest Africa: a superplume exhaust valve in the center of Pangaea, J. Afr. Earth Sci., 26, 89-99, 1998.

Dubuffet, F., Rabinowicz, M., and Monnereau, M.: Multiple scales in mantle convection, Earth Plan. Sci. Lett., 178, 351-366, 2000.

Duncan, R. A. and Hargraves, R. B.: ${ }^{40} \mathrm{Ar}-{ }^{39} \mathrm{Ar}$ geochronology of basement rocks from the Mascarene Plateau, Proc. ODP Sci. Results, 115, 43-51, 1990.

Duncan, R. A. and Pyle, D. G.: Rapid eruption of the Deccan flood basalts at the Cretaceous/Tertiary boundary, Nature, 333, 841843, 1988.

Duncan, R. A. and Richards, M. A.: Hotspots, mantle plumes, flood basalts, and true polar wander, Rev. Geophys., 29, 31-50, 1991.

Duncan, R. A., Hooper, P. R., Rehacek, J., Marsh, J. S., and Duncan, A. R.: The timing and duration of the Karoo igneous event, southern Gondwana, J. Geophys. Res., 102, $18127-$ $18138,1997$.

Dunning, G. R. and Hodych, J. P.: U/Pb zircon and baddeleyite ages for the Palisades and Gettysburg sills of the northeastern United States: Implications for the age of the Triassic/Jurassic boundary, Geology, 18, 795-798, 1990.

Dyment, J.: Structure et évolution de la lithosphére océanique dans l'océan Indien: apport des données magnétiques, Thése de Doctorat és-Sciences, Université Louis Paster, Strasbourg, France, 374 pp, 1991.

Eales, H. V., Marsh, J. S., and Cox, K. G.: The Karoo igneous province: An introduction, in: Erlank, A. J. (Ed.): Petrogenesis of the volcanic rocks of the Karoo Province, Spec. Publ. Geol. Soc. S. Afr., 13, 1-26, 1984.

Ebinger C. J., Yemane, T., Wolde-Gabriel, G., Aronson J. L., and Walter, R. C.: Late Eocene - Recent volcanism and faulting in the southern main Ethiopian rift, J. Geol. Soc. London, 150, 99 108, 1993.

Elliot, D. H., Fleming, T. H., Kyle, P. R., and Foland, K. A.: Longdistance transport of magmas in the Jurassic Ferrar large igneous province, Antarctica, Earth Plan. Sci. Lett., 167, 89-104, 1999.

Encarnación, J., Fleming, T. H., Elliot, D. H., and Eales, H. V.: Synchronous emplacement of Ferrar and Karoo dolerites and the early breakup of Gondwana, Geology, 24, 535-538, 1996.

Fanning, C. M. and Laudon, T. S.: Mesozoic volcanism and sedimentation in eastern Ellsworth Land, West Antarctica; Conflicting evidence for arc migration?, Geol. Soc. Am. Program with abstr., 29, A51517, 1997.

Féraud, G. and Courtillot, V.: Comment on: Did Deccan volcanism pre-date the Cretaceous-Tertiary transition?, Earth Plan. Sci. Lett., 122, 259-262, 1994.

Féraud, G., Alric, V., Fornari, M., Bertrand, H., and Haller, M.: ${ }^{40} \mathrm{Ar} /{ }^{39} \mathrm{Ar}$ dating of the Jurassic volcanic province of Patagonia: migrating magmatism related to Gondwana break-up and subduction, Earth Plan. Sci. Lett., 172, 83-96, 1999.

Franke, W.: Tectonostratigraphic units in the Variscan belt of central Europe, Spec. Pap. Geol. Soc. Am., 230, 67-90, 1989.

Frey, F. A., Coffin, M. F., Wallace, P. J. et al.: Origin and evolution of a submarine large igneous province: the Kerguelen Plateau and Broken Ridge, southern Indian Ocean, Earth Plan. Sci. Lett., 176, 73-89, 2000.

Garfunkel, Z.: Tectonic setting of Phaneorozoic magmatism in Israel, Isr. J. Earth Sci., 38, 51-74., 1989

Garfunkel, Z. and Derin, B.: Permian-early Mesozoic tectonism and continental margin formation in Israel and its implication of the history of the eastern Mediterranean, in: Dixon, J. E. and Robertson, A. H. F. (Eds.): The Geological evolution of the Eastern Mediterranean, Geol. Soc. London, Spec. Publ., 17, 187-201, 1984.

Garfunkel, Z.: Constraints on the origin and history of the Eastern Mediterranean basin, Tectonophys., 298, 5-35, 1998.

George, R., Rogers, N., and Kelley, S.: Earliest magmatism in Ethiopia: Evidence for two mantle plumes in one flood basalts province, Geology 26(10), 923-926, 1998.

Gibson, S. A., Thompson, R. N., Leonardo, O. H., Dickin, A. P., and Mitchell, J. G.: The Late Cretaceous impact of the Trindad mantle plume: Evidence from large-volume, mafic, potassic magmatism in SE Brazil, J. Petrol., 36, 189-229, 1995.

Griffin, W. L., Sutherland, F. L., and Hollis, J. D.: Geothermal profile and crust-mantle transition beneath east-central Queensland: Volcanology, xenolith petrology and seismic data, J. Volcan. Geoth. Res., 31, 177-203, 1987.

Griffiths, R. W. and Campbell, I. H.: Stirring and structure in mantle starting plumes, Earth Plan. Sci. Lett., 99, 66-78, 1990.

Gopala Rao, D. and Krishna, K. S.: Crustal evolution and sedimentation history of the Bay of Bengal since the Cretaceous, J. Geophys. Res., 102 (B8), 17 747-17 768, 1997.

Guiraud, R.: Mesozoic rifting and basin inversion along the northern African Tethyan margin: an overview, in: MacGregor, D. S., Moody, R. T. J., and Clark-Lowes, D. D. (Eds.): Petroleum Geology of North Africa, Geol. Soc. London, Spec. Publ., 132, 217 229, 1998.

Hargraves, R. B., Rehacek, J., and Hooper, P. R.: Palaeomagnetism 
of the Karoo igneous rocks in southern Africa: S. Afr. J. Geol., 100, 195-212, 1997.

Hawkesworth, C., Kelley, S., Turner, S., Le Roex, A., and Storey, B.: Mantle processes during Gondwana break-up and dispersal, J. Afr. Earth, Sci., 28, 239-261, 1999.

Henk, A.: Did the Variscides collapse or were they torn apart?: A quantitative evaluation of the driving forces for postconvergent extension in central Europe, Tectonics, 18, 774-792, 1999.

Hill, R. I.: Starting plumes and continental breakup, Earth Plan. Sci. Lett., 104, 398-416, 1991.

Hodych, J. P. and Dunning, G. R.: Did the Manicouagan impact trigger end-of-Triassic mass extinction?, Geology, 20, 51-54, 1992.

Hofmann, C.: ${ }^{40} \mathrm{Ar} /{ }^{39} \mathrm{Ar}$ et paléomagnétisme des traps d'Ethiopie, du Deccan et de Sibérie, Ph.D. Thesis, Institute de Physique du Globe Paris, 200p, 1997.

Hofmann, C., Courtillot, V., Féraud, G., Rochette, P., Yirgu, G., Ketefo, E., and Pik, R.: Timing of the Ethiopian flood basalts event and implications for plume birth and global change, Nature, 389, 838-841, 1997.

Hole, M. J. and LeMasurier, W. E.: Tectonic controls on the geochemical composition of Cenozoic, mafic alkaline volcanic rocks from West Antarctic, Contr. Miner. Petrol., 117, 187-202, 1994.

Hooper, P. R.: The timing of crustal extension and the eruption of continental flood basalts, Nature, 345, 246-249, 1990.

Hopper, J. R., Mutter, J. C., Larson, R. L., Mutter, C. Z., and the Northwest Australia Study Group: Magmatism and rifted margin evolution: evidence from NW Australia, Geology, 20, 853-857, 1992.

Keeley, M. L. and Wallis, R. J.: The Jurassic system in northern Egypt: II. Depositional and tectonic regims, J. Petrol. Geol., 14, 49-64, 1991.

Keeley, M. L. and Massoud, M. S.: Tectonic control on the petroleum geology of NE Africa, in: MacGregor, D. S., Moody, R. T. J., and Clark-Lowes, D. D. (Eds.): Petroleum Geology of North Africa, Geol. Soc. London, Spec. Publ., 132, 265-281, 1998.

Kent, R.: Lithospheric uplift in eastern Gondwana: Evidence for a long-lived mantle plume system?, Geology, 19, 19-23, 1991.

Kent, R. W., Storey, M., and Saunders, A. D.: Large igneous provinces: Sites of plume impact or plume incubation?, Geology, 20, 891-894, 1992.

Kent, R. W.: Superplumes or supercontinents?: Comment, Geology, 22, 1054-1055, 1994.

Kohn, B. P., Lang, B., and Steinitz, G.: ${ }^{40} \mathrm{Ar} /{ }^{39} \mathrm{Ar}$ dating of the Atlit1 volcanic sequence, northern Israel, Isr. J. Earth Sci., 42, 17-28, 1993.

Kyle, P. R.: McMurdo Volcanic Group, Western Ross embayment, in: LeMasurier, W. E. and Thomson, J. W. (Eds.): Volcanoes of the Antarctic plate and southern Oceans, Am. Geophys. Uni. Antarc. Res. Ser., 48, 19-25, 1990.

Lanyon, R., Varne, R., and Crawford, A. J.: Tasmanian Tertiary basalts, the Balleny plume, and opening of the Tasman Sea (southwest Pacific Ocean), Geology, 21, 555-558, 1993.

Lawver, L. A., Roger, J.-Y., Sandwell, D. T., and Scotese, C. R.: Evolution of the Antarctic continental margins, in: Thomson, M. R., Crame, J. A., and Thomson, J. W. (Eds): Geological evolution of Antarctica, Proc. 5th Int. Symposium on the Antarctic Earth Science, Cambridge, Cambridge University Press, Cambridge, 533-539, 1991.

Lawver, L. A., Gahagan, L. M., and Coffin, M. F.: The development of Palaeo seaways around Antarctica, Antarc. Res. Ser., 56, 7-30,
1992.

LeMasurier, W. E. and Rex, D. C.: The Marie Byrd Land volcanic province and its relation to the Cenozoic West Antarctic rift system, in: Tingey, R. J. (Ed.): The Geology of Antarctica, Clarendon Press, Oxford, 249-284, 1991.

Lorenz, V. and Nicholls, I. A.: The Permocarboniferous Basin and Range province of Europe. An application of plate tectonics, in: Falke, H. (Ed.): The continental Permian in Central, West, and South Europe, Nato ASI Ser., C22 D - Reidel, Dordrecht, 313 342, 1976

Lorenz, V. and Nicholls, I. A.: Plate and intraplate processes of Hercynian Europe during the Late Paleozoic, Tectonophys., 107, 25-56, 1984.

Ludden, J. N.: Radiometric age determinations for basement from sites 765 and 766, Argo Abyssal Plain and northwest Australian margin, in: Gradstein, F. M., Ludden, J. N., and Adamson, A. C. (Eds.): Proceedings of the Ocean Drilling Program, Scientific Results of Leg 123, College Station, Texas, 557-559, 1992.

Maluski, H., Coulon, C., Popoff, M., and Baudin, P.: ${ }^{40} \mathrm{Ar} /{ }^{39} \mathrm{Ar}$ chronology, petrology and geodynamic setting of Mesozoic to early Cenozoic magmatism from the Benue Trough, Nigeria, J. Geol. Soc. London, 152, 311-326, 1995.

Martin, G.: Geologie des Küstengebietes von Nordwest-Afrika südlich der Sahara. Neue Erkenntnisse aus der Erdölexploration, Giessener Geologische Schriften, 30, 160 S., 1982.

Marzoli, A., Renne, P. R., Piccirillo, E. M., Ernesto, M., Bellini, G., and De Min, A.: Extensive 200-million-year-old continental flood basalts of the Central Atlantic magmatic Province, Science, 284, 616-618, 1999.

Massa, D. and Delort, T.: Evolution du bassin de Syrte (Libye) du Cambrien au Crétacé basal, Bull. Soc. Géol, France, 26, 10871096, 1984.

McHone, J. G.: Broad-terrane Jurassic flood basalts across northwestern North America, Geology, 24, 319-322, 1996.

McKenzie, D.: A possible mechanism for epeirogenic uplift, Nature, 307, 616-618, 1984.

Ménard, G. and Molnar, P.: Collapse of a Hercynian Tibetan Plateau into a late Palaeozoic European Basin and Range province, Nature, 334, 235-237, 1988.

Meneisy, M. Y.: Vulcanicity, in: Said, R. (Ed.): The Geology of Egypt, A. A. Balkema, Rotterdam, Netherlands, 157-172, 1990.

Millar, I. L. and Pankhurst, R. J.: Rb-Sr geochronology of the region between the Antarctic Peninsula and the Transantarctic Mountains: Haag Nunataks and Mesozoic granitoids, in: McKenzie, G. D. (Ed.): Gondwana Six: Structure, Tectonics and Geophysics, Am. Geophys. Union, Geophys. Monogr., 40, 151-160, 1987.

Millar, I. L., Milne, A. J., and Whitham, A. G.: Implications of SmNd garnet ages for the stratigraphy of northern Graham Land, Antarctic Peninsula, Zentralblatt für Geologie und Paläeontologie, Teil 1, 1/2, 97-104, 1990.

Milner, S. C., Le Roex, A. P., and Watkins, R. T.: Rb-Sr age determinations of rocks from the Okenyenya igneous complex, northwestern Namibia, Geol. Mag., 130, 335-343, 1993.

Minor, D. R. and Mukasa, S. B.: A new crystallization age and isotope geochemistry of the Dufek layered mafic intrusion: Implications for formation of the Ferrar volcanic province, EOS (Trans. Am. Geopys. Un.), 76, 285, 1995.

Monod, O. and Akay, E.: Evidence for a Late Triassic Early Jurassic orogenic event in the Taurides, in: Dixon, J. E. and Robertson, A. H. F. (Eds.): The Geological Evolution of the Eastern Mediterranean, Geol. Soc. London, Spec. Publ., 17, 113-122, 
1984.

Morgan, W. J.: Convection plumes in the lower mantle, Nature, 230, 42-43, 1971.

Morgan, W. J.: Hotspot tracks and the opening of the Atlantic and Indian oceans, in: Emiliani, C. (Ed.): The Sea, Wiley, New York, 443-487, 1981.

Mortimer, N. and Parkinson, D.: Hikurangi Plateau: a Cretaceous large igneous province in the southwest Pacific Ocean, J. Geophys. Res., 101, 687-696, 1996.

Mukasa, S. B., Dalziel, I. W. D., and Pankhurst, R. J.: U-Pb and $\mathrm{Ar} / \mathrm{Ar}$ age constraints on the development and subsequent fragmentation of Gondwanaland's Pacific margin, Marie Byrd Land, Antarctica, EOS, Trans Am. Geophys. Uni., 75, 692, 1994.

Mutter, J. C., Buck, W. R., and Zehnder, C. M.: Convective partial melting. 1. A model for the formation of thick basaltic sequences during the initiation of spreading, J. Geophys. Res., 93(B2), 1031-1048, 1988.

Mutter, J. C., Larson, R. L., and the Northwest Australia Study Group: Extension of the Exmouth plateau, offshore northwest Australia: deep seismic reflection/refraction evidence for simple and pure shear mechanism, Geology, 17, 15-18, 1989.

Neumann, E.-R., Olsen, K. H., Baldridge, W. S., and Sundvoll, B.: The Olslo Rift: a review, Tectonophys., 208, 1-18, 1992.

Nürnberg, D. and Müller, R. D.: The tectonic evolution of the South Atlantic from Late Jurassic to present, Tectonophys., 191, 27-53, 1991.

Oliveira, E. P., Tarney, J., and João, X. J.: Geochemistry of the Mesozoic Amapá and Jari dyke swarms, northern Brazil: Plumerelated magmatism during the opening of the central Atlantic, in: Parker, A. J., Rickwood, P. C. and Tucker, D. H. (Eds.): Mafic Dykes and Emplacement Mechanisms, Balkema, Rotterdam, 173-183, 1990.

Olson, P., Silver, P. G., and Carlson, R. W.: The large-scale structure of convection in the Earth's mantle, Nature, 344, 209-215, 1990.

Omar, G. I. and Steckler, M. S.: Fission track evidence on the initial rifting of the Red Sea; two pulses, no propagation, Science, 270, 1341-1344, 1995.

Palais, D. G., Mukasa, S. B., and Weaver, S. D.: U-Pb and Ar/Ar geochronology for plutons along the Ruppert and Hobbs coasts, Marie Byrd Land, West Antarctica: Evidence for rapid transition from arc to rift related magmatism, EOS, Trans Am. Geophys. Uni., 74, 123, 1993.

Pankhurst, R. J., Leat, P. T., Sruoga, P., Rapela, C. W., Marquez, M., Storey, B. C., and Riley, T. R.: The Chon Aike province of Patagonia and related rocks in West Antarctica: A silicic large igneous province, J. Volcan. Geotherm. Res., 81, 113-136, 1998.

Piccirillo, E. M., Melfi, A. J., Comin-Chiaramonti, P., Bellieni, G., Ernesto, M., Marques, L. S., Nardy, A. J. R., Pacca, I. G., Roisenberg, A., and Stolfa, D.: Continental flood volcanism from the Paraná basin (Brazil), in: Macdougal, J. D. (Ed.): Continental flood basalts, Dordrecht, Netherlands, Kluwer, 195-238, 1988.

Plummer, P. S.: The Amirante ridge/trough complex: Response to rotational transform rift/drift between Seyschelles and Madagascar, Terra Nova, 8, 34-47, 1996.

Plummer, P. S. and Belle, E. R.: Mesozoic tectono-stratigraphic evolution of the Seychelles microcontinent, Sedim. Geol., 96, 73-91, 1995.

Powell, C. McA., Roots, S. R., and Veevers, J. J.: Pre-breakup continental extension in East Gondwanaland and the early opening of the eastern Indian Ocean, Tectonophys., 155, 261-283, 1988.

Pringle, M. S., Storey, M., and Wijbrans, J.: ${ }^{40} \mathrm{Ar} /{ }^{39} \mathrm{Ar}$ geochronology of mid-Cretaceous Indian Ocean basalts: Constraints on the origin of large flood basalt provinces, in: Fall meet. Suppl., San Francisco, Eos Trans. AGU, 75, p. 728, 1994.

Rabinowitz, P. D. and LaBrecque, J.: The Mesozoic South Atlantic Ocean and evolution of its continental margins,J. Geophys. Res., 84, 5973-6002, 1979.

Radhakrishna, T., Maluski, H., Mitchell, J. T., and Joseph, M.: ${ }^{40} \mathrm{Ar} /{ }^{39} \mathrm{Ar}$ and $\mathrm{K} / \mathrm{Ar}$ geochronology of the dykes from the south Indian granulite terrain, Tectonophys., 304, 109-129, 1999.

Renne, P. R., Ernesto, M., Pacca, I. G., Coe, R. S., Glen, J. M., Prevot, M., and Perrin, M.: The age of Paraná flood volcanism, rifting of Gondwanaland, and the Jurassic-Cretaceous boundary, Science, 258, 975-979, 1992.

Renne, P. R., Deckart, K., Ernesto, M., Féraud, G., and Piccirillo, E. M.: Age of the Ponta Grossa dike swarm (Brazil), and implications to Paraná flood volcanism, Earth Plan. Sci. Lett., 144, 199-211, 1996.

Renne, P. R., Ernesto, M., and Milner, S. C. (Eds.): Tectonic and magmatic evolution of the Paraná-Etendeka large igneous province and south Atlantic margins, J. Geodynamics ,28, Spec. Issue, 1999.

Reynolds, P. O., Schandelmeier, H., and Semtner, A. K.: The Early Cretaceous (Valanginian, ca. $138 \mathrm{Ma}$ ), in: Schandelmeier, H., Reynolds, P. O., and Semtner, A. K. (Eds.): PalaeogeographicPalaeotectonic Atlas of north-eastern Africa, Arabia, and adjacent areas, A. A. Balkema, Rotterdam, Netherlands, 65-71, 1997.

Reyre, D.: Remarques sur l'origine et l'evolution des bassins sédimentaires africains de la côte atlantique, Bull. Soc. Géol. France, 6, 1041-1059, 1984.

Richards, M. A., Duncan, A. R., and Courtillot, V. E.: Flood basalts and hot-spot tracks: plume heads and tails, Science, 246, 103107, 1989.

Rocholl, A., Stein, M., Molzahn, M., Hart, S. R., and Wörner, G.: Geochemical evolution of rift magmas by progressive tapping of a stratified mantle source beneath the Ross Sea Rift, Northern Victoria Land, Antarctica, Earth Plan. Sci. Lett., 131, 207-224, 1995.

Sakai, H., Funaki, M., Sato, T., Takigami, Y., Sakai, H., and Hirooka, K.: Paleomagnetic study with ${ }^{40} \mathrm{Ar} /{ }^{39} \mathrm{Ar}$ dating of Rajmahal hills and Mahanadi graben in India - reconstruction of Gondwanaland, J. Geol. Soc. Jap., 103(3), 192-202, 1997.

Schilling, J.-G., Kingsley, R. H., Hanan, B. B., and McCully, B. L.: Nd-Sr-Pb isotopic variations along the Golf of Aden: Evidence for Afar mantle plume-continental lithosphere interaction, J. Geophys. Res., 97(B7), 10 927-10 966, 1992.

Sebai, A., Féraud, G., Bertrand, H., and Hanes, J.: ${ }^{40} \mathrm{Ar} /{ }^{39} \mathrm{Ar}$ dating and geochemistry of tholeiitic magmatism related to the early opening of the Central Atlantic rift, Earth Plan. Sci. Lett., 104, 455-472, 1991.

Segev, A., Goldshmidt, V., Itamar, A., and Rybakov, M.: The effects of Mesozoic magmatism on the composition, structure and metallic mineralization in the Ramon area (southern Israel): magnetometric and gravimetric evidence, Isr. J. Earth Sci., 45, 89-112, 1996.

Segev, A.: Magmatic cyclicity in the Afro-Arabian Plate: Mantle convection generated, in: ICOG-9 (Abstr.), Beijing, Chin. Sci. Bull., 43, 115, 1998.

Segev, A.: Synchronous magmatic cycles during the fragmentation of Gondwana: radiometric ages from the Levant and other provinces, Tectonophys., 325(3-4), 257-277, 2000a.

Segev, A.: The principal Phanerozoic tectono-magmatic periods in the Levant and their stratigraphic record, Geol. Surv. Isr. Curren. 
Res., 12, 115-124, 2000b.

Segev, A. and Lang, B.: ${ }^{40} \mathrm{Ar} /{ }^{39} \mathrm{Ar}$ and K/Ar dating of some Mesozoic igneous rocks from Israel: whole rock and mineral separates, Isr. Geol. Surv. Rep., GSI/15/01, 35 p., 2001.

Segev, A. and Eshet, Y.: Significance of $\mathrm{Rb} / \mathrm{Sr}$ age of Early Permian volcanics, Helez Deep 1A borehole, central Israel (in press), 2003.

Sengör, A. M. C.: Mid-Mesozoic closure of Permo-Triassic Tethys and its implications, Nature, 29, 590-593, 1979.

Sengör, A. M. C., Yilmaz, Y., and Süngürlu, O.: Tectonics of the Mediterranean Cimmerides: nature and evolution of the western termination of Palaeo-Tethys, in: Dixon, J. E. and Robertson, A. H. F. (Eds.): The Geological Evolution of the Eastern Mediterranean. Geol. Soc. London, Spec. Publ., 17, 77-112, 1984.

Serencsits, C. McC., El Ramly, M. F., Faul, H., Foland, K. A., Hussein, A. A., and Lutz, T. M.: Alkaline ring complexes in Egypt: their ages and relationship in time, J. Geophys. Res., 86(B4), 3009-3013, 1981.

Sheth, H. C.: Flood basalts and large igneous provinces from deep mantle plumes: fact, fiction, and fallacy, Tectonophys., 311, 129, 1999.

Stampfli, G. M.: Tethyan oceans, in: Bozkurt, E., Winchester, J. A., and Piper, J. D. A. (Eds.): Tectonic and Magmatism in Turkey and the Surrounding Area, Geol. Soc. London, Spec. Publ., 173, 1-23, 2000.

Stein, M. and Hofmann, A. W.: Fossil plume head beneath the Arabian lithosphere?, Earth Plan. Sci. Lett., 114, 193-209, 1992.

Stein, M. and Hofmann, A. W.: Mantle plumes and episodic crustal growth, Nature, 372, 63-68, 1994.

Stewart, K., Turner, S., Kelley, S., Hawkesworth, C., Kirstein, L., and Mantovani, M.: 3-D ${ }^{40} \mathrm{Ar}-{ }^{39}$ Ar geochronology in the Paraná continental flood basalt province, Earth Plan. Sci. Lett., 143, 95 109, 1996

Storey, B. C., Alabaster, T., Hole, M. J., Pankhurst, R. J., and Weaver, H. E.: Role of subduction-plate boundary forces during the initial stages of Gondwana break-up; evidence from the proto-Pacific margin of Antarctica, in: Storey, B. C., Alabaster, T., and Pankhurst, R. J. (Eds.): Magmatism and the causes of continental break-up, Geol. Soc. Spec. Publ., 68, 149-164, 1992.

Storey, B. C.: The role of mantle plumes in continental breakup: case histories from Gondwanaland, Nature, 377, 301-308, 1995.

Storey, B. C. and Kyle P. R.: An active mantle mechanism for Gondwana breakup, South Afr. J. Geol., 100(4), 283-290, 1997.

Storey, B. C., Leat, P. T., Weaver, S. D., Pankhurst, R. J., Bradshaw, J. D., and Kelley, S.: Mantle plumes and Antarctica-New Zealand rifting: evidence from mid-Cretaceous mafic dykes, J. Geol. Soc., London, 156, 659-671, 1999.

Storey, M., Mahoney, J. J., Saunders, A. D., Duncan, R. A., Kelley, S. P., and Coffin, M. F.: Timing of hot spot-related volcanism and the breakup of Madagascar and India, Science, 267, 852855,1995

Stump, E. and Fitzgerald, P.: Episodic uplift of the Transantarctic Mountains, Geology, 20, 161-164, 1992.

Sutherland, R.: Tertiary volcanism, in: Burrett, C. F. and Martin, E. L. (Eds.): Geology and mineral resources of Tasmania, Geol. Soc. Austr. Spec. Publ., 15, 383-386, 1989.

Sutherland, R.: Basement geology and tectonic development of the greater New Zealand region: an interpretation from regional magnetic data. Tectonophys. 308, 341-362, 1999.

Sutter, J. F.: Progress on geochronology of Mesozoic diabases and basalts, in: Robinson, G. R. and Froelich, A. J. (Eds.): Workshop on the Early Mesozoic Basins of the Eastern United States,
Proceed, 2th U.S. Geol. Surv. Circ., 946, 110-114, 1985.

Tackley, P. J.: Mantle convection and plate tectonics: toward an integrated physical and chemical theory, Science, 288, 2002-2007, 2000 .

Torsvic, T. H., Tucker, R. D., Ashwal, L. D., Eide, E. A. Rakotosolofo, N. A., and de Wit, M. J.: Late Cretaceous magmatism in Madagascar: palaeomagnetic evidence for a stationary Marion hotspot, Earth Plan. Sci. Lett., 164, 221-232, 1998.

Turner, S., Regelous, M., Kelley, S., Hawkesworth, C., and Mantovani, M.: Magmatism and continental break-up in the South Atlantic: High precision ${ }^{40} \mathrm{Ar}-{ }^{39} \mathrm{Ar}$ geochronology, Earth Plan. Sci. Lett., 121, 333-348, 1994.

VanDecar, J. C., James, D. E., and Assumpcão, M.: Seismic evidence for a fossil plume beneath South America and implications for plate driving forces, Nature, 378, 25-31, 1995.

van der Hilst, R. D. and Seno, T.: Effects of relative plate motion on the deep structure and penetration depth of slabs below IzuBonin and Mariana island arcs, Earth Plan. Sci. Lett., 120, 395407, 1993.

van der Hilst, R. D., Widiyantoro, S., and Engdahl, E. R.: Evidence for deep mantle circulation from global tomography, Nature, 386, 578-585, 1997.

van Wees, J. D., Stephenson, R. A., Ziegler, P. A., Bayer, U., McCann, T., Dadlez, R., Gaupp, R., Narkiewicz, M., Bitzer, F., and Scheck, M.: On the origin of the Southern Permian Basin, Central Europe, Marine Petroleum Geol., 17(1), 43-59, 2000.

Vaughan, A. P. M. and Millar, I. L.: Early Cretaceous magmatism during extensional deformation within the Antarctic Peninsula magmatic arc., J. S. Am. Earth Sci., 9, 121-129, 1995.

Vaughan, A. P. M., Wareham, C. D., and Millar, I. L.: Granitoid pluton formation by spreading of continental crust: the Wiley Glacier complex, northwest Palmer Land, Antarctica, Tectonophys., 283, 35-60, 1997.

Vaughan, A. P. M., Wareham, C. D., Johnson, A. C., and Kelley, S. P.: Lower Cretaceous, syn-extensional magmatic anomalies: The Pacific Margin Anomaly (PMA), western Palmer Land, Antarctica, Earth Plan. Sci. Lett., 158, 143-155, 1998.

Veevers, J. J., Stagg, H. M. J., Willcox, J. B., and Davies, H. L.: Pattern of slow seafloor spreading $(<4 \mathrm{~mm} /$ year) from breakup (96 Ma) to A20 (44.5 Ma) off the southern margin of Australia, BMR J. Aus. Geol. Geophys., 11, 499-507, 1990.

Veevers, J. J., Powell, C. McA., and Roots, S. R.: Review of seafloor spreading around Australia, 1. Synthesis of the patterns of spreadings, Aust. J. Earth Sci., 38, 373-389, 1991.

Venkatesan, T. R., Pande, K., and Goplan, K.: Did Deccan volcanism pre-date the Cretaceous /Tertiary transition?, Earth Plan. Sci. Lett., 119, 181-189, 1993.

Vogt, P. R. and Johnson, G. L.: A longitudinal seismic reflection profile of the Reykjanes Ridge: Part II - Implication for the mantle hotspot hypotethis, Earth Plan. Sci. Lett., 18, 49-58, 1973.

von Rad, U., Exon, N. F., Boyd, R., and Haq, B. W.: Mesozoic paleoenvironment of the rifted margin off NW Australia (ODP Legs 122/123). Synthesis of results from scientific drilling in the Indian Ocean, Am. Geophys. Uni. Geophys. Monog., 70, $157-$ 184, 1992.

Waight, T. E., Weaver, S. D., and Muir, R. J.: Mid-Cretaceous granitic magmatism during the transition from subduction to extension in southern New Zealand: a chemical and tectonic synthesis, Lithos, 45, 469-482, 1998.

Weaver, S. D., Storey, B. C., Pankhurst, R. J., Mukasa, S. B., DiVenere, V. J., and Bradshaw, J. D.: Antarctica - New Zealand rifting and Marie Byrd Land lithospheric magmatism linked to 
ridge subduction and mantle plume activity, Geology, 22, 811814, 1994.

White, R. and McKenzie, D.: Magmatism at rift zones: The generation of volcanic continental margins and flood basalts, J. Geophys. Res., 94, 7685-7729, 1989.

White, R. S. and McKenzie, D.: Mantle plumes and flood basalts, J. Geophys. Res., 100(B9), 17 543-17 585, 1995.

Whitehead, J. A. and Chen, M. M.: Thermal instability and convection of a thin layer bounded by a stably stratified region, J. Fluid Mech., 40, 549-576, 1970.

Willcox, J. B. and Stagg, H. M. J.: Australia's southern margin: a product of oblique extension, Tectonophys., 173, 269-281, 1990.

Wilson, M. and Guiraud, R.: Magmatism and rifting in Western and Central Africa, from Late Jurassic to Recent times, Tectonophys., 213, 203-225, 1992.

Wilson, M.: Thermal evolution of the Central Atlantic passive mar- gins: continental break-up above a Mesozoic super-plume, J. Geol. Soc. London, 154, 491-495, 1997.

Wilson, M. and Guiraud, R.: Late Permian to Recent magmatic activity on the African-Arabian margin of Tethys, in: MacGregor, D. S., Moody, R. T. J., and Clark-Lowes, D. D. (Eds.): Petroleum Geology of North Africa, Geol. Soc., London, Spec. Publ., 132, 231-263, 1998.

Zeyen, H., Volker, F., Wehrle, V., Fuchs, K., Sobolev, S. V., and Altherr, R.: Styles of continental rifting: Crust-mantle detachment and mantle plumes, Tectonophys., 278, 329-352, 1997.

Ziegler, P. A.: Evolution of Laurussia, Kluwer Academic Publishers, Dordrecht, Boston, London, 102 p, 1989.

Ziegler, P. A.: Geological Atlas of Western and Central Europe, Shell Int. Pet. Maatschappij, The Hague, 239 pp, 1990.

Ziegler, P. A.: Plate-moving mechanisms: Their relative importance, J. Geol. Soc., London, 150, 927-940, 1993. 